\title{
Ikonográfia és életképek a 20. század eleji Magyarországról
}

\section{MikONYA GYÖRGY}

Eötvös Loránd Tudományegyetem, Tanító- és Óvóképző Kar

\begin{abstract}
Napjainkban a neveléstörténeti kutatásban egyre gyakrabban használnak fel ikonográfiai elemeket, mert a képek nagyon hatásosan egészitik ki a szöveges és a narrativ forrásokat. Jelen esetben több fotográfus fényképei adták a kutatás kiindulópontját. Az összesen 146 fényképböl álló katalógus - a 20. század elejére datált fényképek felhasználásával - különbözö albumokból, fotótárakból lett összeállitva. Ennek során a következö tematika szerint történt a csoportositás: szociófotók, gyermekjátékok, tehetös családok gyermekei, gyermek a dadájával, ételosztás gyermekeknek, gyermekmunka, gyermekkori tragédiák, roma gyermekek, zsidó gyermekek, menekültek lakásviszonyai. A multiperspektivikus ábrázolás és az értelmezö szövegkorpusz együttese alaposabb bepillantást enged a a 20. század eleji magyar gyermeki lét történéseibe.
\end{abstract}

Kulcsszavak: müvészfotók, tematizált gyermekkép, komplex megjelenités - önálló kép, párhuzamos bemutatás, sorba rendezés

\section{Bevezetés}

A neveléstörténeti kutatásokban az utóbbi időben egyre elterjedtebb ikonográfiai elemek és életrajzokból származó narratívák együttes vagy más módszerekkel kombinált felhasználása. Az ikonográfiai források vizsgálata sokszor fontosabb, mint az írottaké (L. Menyhért, 2008. 158. o.), különösen így van ez, ha olyan jelenséget kutatunk, amelyről az adott időszakban nem, vagy nagyon kevés írásos anyag keletkezett. A korábban preferált kizárólagosan levéltári kutatások már nem adnak teljes képet a múltról. Különösen igaz ez a 20. század esetében, ahol a források jelentős része már nem papíralapú dokumentum. „Aki tehát jelenkor történettel komolyan foglalkozik, és nem vizsgál mást, csupán hagyományos forrásokat, az nem fogja megismerni a témájára vonatkozó történeti értékkel bíró releváns anyagok jelentős részét. Közülük is különös figyelmet érdemelnek a narratív források mellett a fényképek (és mozgóképek) mint történeti források" (Szécsényi, 2016. 13-14. o.). A képi elemek közül jelen esetben a fotók felhasználása történik. Minden fotó folyamatos, megszakítatlan kódokat közvetít, azaz kódok szerint elrendezett szimbólumokat tartalmaz (Gayer, 1998. 90. o.). A fotónak lehet egy szó szerinti denotált üzenete, ami lényegében arra utal, hogy mit ábrázol az adott fénykép. A kutatás szempontjából néha fontosabb a konnotált mondanivaló, amely olyan összetett képzettársítás, érzés, amelyet a kép sugall, vagyis az, amire a fénykép megtekintésekor asszociálunk (Sántha, 2011. 61. o.). A hagyományos képi ábrázolásokkal szemben csak a fénykép sajátossága, hogy a fotós szándéka nélkül is megőrizhet olyan mozzanatokat, amelyek a későbbi elemző számára fontosak lehetnek. „Az írott forrásokkal összehasonlítva a fénykép előnye, hogy mentes a nyelvi kötöttségektől, ezért egyedülállóan alkalmas egyetemes történeti összehasonlításra (Stemlerné Balogh, 2008. 7. o.). Ezért a fénykép összekötő kapocs lehet az ikonográfiai és az életrajzi, narratívajellegü források között. A fényképnek fontos szerepe lehet az egyéni és a közösségi emlékezet tartalmának formálásában. A fénykép sokszor az írott szövegnél hatásosabban kelti fel a figyelmet, megerősíthet és nyomatékosíthat korábbi felvetéseket. Hasonló véleményt képvisel Gyurgyák János, szerinte a történészek számára fontosabbak a képi források annál, hogy csak illusztrációként használják őket. Hiba, ha „a képeket nem tekintik önálló, mással nem helyettesíthető forrásnak, amelyeket 
Ikonográfia és életképek a 20. század eleji Magyarországról

ugyanolyan gonddal kell tanulmányozni és vizsgálni, mint a szöveges dokumentumokat" (Gyurgyák, 2008. 9-10. o.). A kutató számára a legnagyobb kihívást a képek értelmezése, „megszólaltatása” jelenti, ez azért nehéz, mert a korrekt értelmezéshez birtokában kell lenni az akkori mindennapi élet ismeretanyagának, azaz a kortársi tudásnak. Sokak szerint a nehézségek ellenére, még mindig a fénykép az egyik leghitelesebb ember és tárgyábrázolás ${ }^{1}$.

\section{Tipikus élethelyzetek megjelenése és hatása}

A hosszú - utólag konszolidáltnak nevezhető 19. századot - viharos időszak követi. Az első világháború eseményeit, ahová dicsőségre és hírnévre vágyva - sokszor még önkéntesként - vonultak a férfiak, forradalmak és keserü csalódás követte. A világgazdasági válság és a trianoni békeszerződés hatása csak fokozta az elkeseredettséget, ami sok más tényezővel együtt elvezetett a második világháborúhoz. A háborús körülmények ikonográfiai feldolgozásához használhatók a haditudósítók anyagai, az újságokban megjelent fényképek és a hozzájuk kapcsolt kommentárok. Utóbbiak esetében számolni kell az ideológiai okokból bekövetkezett tendenciózus beállításokkal. A magyar fotográfiatörténetben nagy hagyománya van a két világháború közötti időszakban virágkorát élő szociofotózásnak, amely témáját tekintve többnyire a nehéz körülmények között élőkről tudósít. Erről az időszakról meglehetősen nagy számban maradtak fenn amatőr felvételek is, ezek elemzése sok tekintetben kiegészítheti, pontosíthatja a hivatásos fotográfusok anyagát, de jelen esetben ezek nem képezik a tanulmány tárgyát. Neveléstudományi szempontból kiemelten fontos a kor gyermekképének vizsgálata, ennek nemcsak történeti jelentősége

\footnotetext{
${ }^{1}$ Kivéve az eleve manipulációs szándékkal készült felvételeket, amilyenek Sztálin alulról készített és az arcot retusált fotói vagy Hitler fényképei és a kiretusálással eltüntetett személyek. Stemlerné Balog Ilona (2009) könyvében egy egész fejezetben 200-207. o. foglalkozik a manipulált fényképek magyarországi vonatkozásaival.
}

van, hanem az utólagos hatások miatt, akár még napjaink nemzedékének nézeteire is hatással lehet. Az anya-gyermek kapcsolatok kisgyermekkorban bekövetkezett tömeges méretű traumatizálódásának a későbbi életvitelben súlyos következményei lehetnek. A legújabb epigenetikai kutatások szerint az erős stresszhatásokkal járó élethelyzetek akár több generáción keresztül is megjelenhetnek. Igaz, hogy a DNS-szekvenciák maguk nem változnak a környezet hatására, de a müködésük módja, azaz melyik elemük zárt vagy nyitott, az igen. Bizonyított tény, hogy a háborús körülmények között születettek kötődését ezek a hatások befolyásolták és ez azóta is tovább gyűrüzik. Benda József például ebben látja a népességfogyás egyik legfontosabb összetevőjét (Benda, 2016. 20. o.). Bowlby kutatási eredményei szerint a korai, érzékeny és részben genetikailag, illetve a tudattalanban kódolt anya-gyermek kapcsolat zavartalanságában teremtődik meg, épül fel, szilárdul meg és válik alkalmassá a személyiség arra, hogy képes legyen később szeretetet adni és elfogadni. Ennek a kötődési mintának a kialakulása biztosítja az egyén, a család és a társadalom számára az élet folytonosságát. Amennyiben a spontánul jelentkező késztetések megnyilvánulásait külső erők gátolják, büntetik vagy ingerszegény a környezet - amely sokak számára tipikusan ilyen -, azaz a gyermek sokat van egyedül, vagy nem kap megerősítést, visszajelzést, akkor magatartásában és gondolkodásában érzékelhető szociális deficit alakul ki. Ez olyan viselkedési anomáliákban jelentkezik, mint szétszórtság, figyelmetlenség, a céltudatosság hiánya, határozatlanság vagy a magabiztosság hiánya. Az hogy valaki szeret-e tanulni, vagy sem, motivált-e új ismeretek szerzésére vagy sem, attól függ, hogy kisgyermekkorában ki tudott-e alakulni nála a gondolkodási folyamat motivációs bázisa. A kisgyermekkorban megfigyelhető pszicho-motorikus teljesítménykülönbségek és a tanulási zavarok nagy része is erre vezethető vissza (Sziklai, 1993. 78. o.). 


\section{A kutatás menete és módszerei}

A kutatás kapcsolódik ahhoz a felfogáshoz, amelynek részeként a képtudomány módszerei a neveléstudományi és társadalomtudományi kutatásban egyre elfogadottabbak. Számos, az utóbbi időben publikált kiváló nemzetközi (Schmitt, 1997; Buntzés Erdmann, 2004, 2009; Pilarczyk és Mietzner, 2005) és hazai tanulmány is utal erre (Kéri, 2003, 2009; Géczi, 2010; Darvai, 2011; Endrődy-Nagy, 2015). A fényképek történeti felhasználása korlátozott, hiszen a kultúra vizuális részét örökítik meg és viszik tovább. A képeken információk vannak elrejtve a mindennapi élet történéseiről és más, a fényképész számára fontosnak tűnő eseményekről. A fényképek a valóságot nem tükörképként dokumentálják, hanem egy adott nézőpontból, egy speciális perspektívából ábrázolják, ezért a fénykép a valóság lekicsinyítése, részlet, amely szelekció eredménye. A kameratechnika, a fényképészt bizonyos optikai látásmódokra korlátozza, aki csak ezeket tudja felhasználni a képalkotás során. Ehhez tartozik a blende kiválasztása és a záridő, a gyújtótávolság beállítása és a vágási lehetőségek közötti válogatás (Pilarczyk és Mietzner, 2010. 6. o.).

A kutatás során az első döntés a fotósok körére vonatkozott és ennek nyomán az amatőr képeket terjedelmi okokból eleve mellőzni kényszerültem. A hivatásosok közül a művészi fotós és a sajtófotós között választhattam volna. De ez azért nem célszerü, mert sok számba jöhető fotós mindkét területre besorolható, így ezt a csoportot együtt kezeltem. A következő lépést az ily módon számba jöhető fotósok kiválasztása és műveik hozzáférhetőségének feltérképezése jelentette. Így összesen 14 fotós került a mintába. A fotókat albumokban, katalógusokban, életművet bemutató kötetekben on-line gyüjteményekben és múzeumi fényképtárakban kerestem. A képanyag előzetes tanulmányozása során - miután fotószéria készítését tűztem ki célul - összehasonlítható, címszavakba rendezhető kritériumokat kerestem. A kritériumok biztosítják a kontextusról megszerezhető információk minimumát, amelyek nélkül a fényképeket nem lehetne helyesen értelmezni, valamint nem lehetne nagyobb mennyiséget értelemszerüen és hatékonyan rendezni és tagolni. A képanyag tanulmányozása során a következő motívumok kerültek elő nagyobb számban:

- beállított műtermi gyermekfotók,

- gyermekek játékkal vagy más tárggyal,

- valamilyen munkát végző vagy abban segédkező gyermek,

- lakásviszonyokra utaló képek,

- egyes társadalmi csoportok élethelyzetét bemutató fotók

- és rendkívüli eseményekről tudósító képek.

A következő feladat a kiválasztott képekből egy elektronikus képi adatbank létrehozása volt, ez összesen 146 fotóból állt össze. Minden fotónál dokumentáltak az alapadatok, a keletkezés idejéről, a fotós személyéről, a fotóhoz tartozó címről és amennyiben ez rendelkezésre állt a fotó készítésének körülményeiről és a fotós szándékáról. Az így összegyűjtött képanyagból a továbbiakban meghatározott tematika szerint sorozatokat, illetve önálló képeket kívánok bemutatni.

\section{A fotók bemutatása és értelmezése}

Elsőként az érdekesség kedvéért rögtön a szociofotók és a műtermi fotográfiák szándékos egymás mellé helyezésével igyekszem ezen az egész időszakon végigvonuló feszültséget érzékeltetni, ami a különböző élethelyzetű gyermekek körülményeiből adódik.

A fotótörténész Albertini Béla szerint „A szociofotó - szociális fénykép - készítésének célja valamilyen hatás elérése. Ha keletkezését követően nem kerül nyilvánosság elé, később is lehet történeti-társadalmi dokumentum, adhat esztétikai élményt, de funkcionális jelentőségét elveszti" (idézi Stemlerné Balog, 2009. 140. о.) 

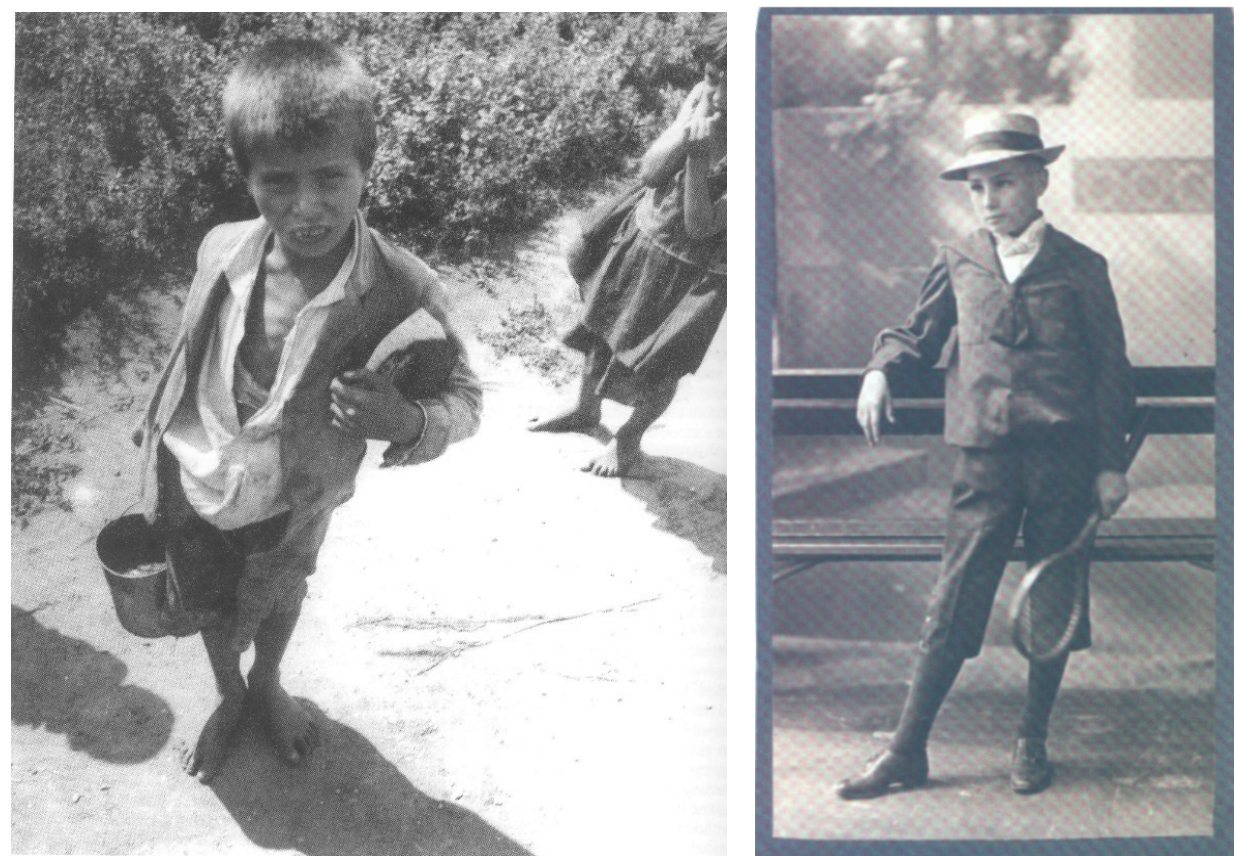

1-2. kép: „kannás fiư”; Fiú teniszütővel

A két fénykép egymás mellé helyezése szándékos és a célja kifejezetten az, hogy szemléltesse a két élethelyzet közötti alapvető eltérést. Ebben az esetben a képi elem az írásos szövegnél hitelesebben utal a különbségre. A „kannás fiú” portréján figyelmet érdemel a nem méretes ruházat, a cipő hiánya, a csupasz mellkason látszó, alultápláltságra utaló bordák, maga az egész testtartás és a háttérben a valamin sopánkodó, hasonlóan szegényes ruházatú kislány portréja. Jellemző az is, hogy a kisfiút tevékenység közben fényképezték, mégpedig úgy, hogy mindkét kezében tart valamit. A „fiú teniszütővel” portréja alapvetően biztonságot és öntudatosságot sugall. A testtartás és az arckifejezés is biztos családi háttérről, jó iskoláról, reményteljes jövőről tudósít. A ruházat és különösen az elegáns kalap eleve eleganciát ad a fotónak, amelyet még hatásosan egészít ki a teniszütő a hosszú kézujjakkal, valamint a nyilvánvalóan nem fizikai munkára termett, világítóan fehér kézfej kiemelése jellemző erre a fényképre.

\section{A gyermekkori játék}

A gyermekek életéből sohasem hiányzik a játék és ők szinte mindenütt feltalálják magukat, a legegyszerübb élethelyzetekben is igyekeznek természetes ösztönükből fakadóan, valamilyen számukra izgalmas dolgot találni. Különösen érdekes megnyilvánulás ez egy örökösen megmaradó játék esetében, ami jelen esetben nem más, mint a kavicsdobálás, megfelelően lapos, kacsázásra alkalmas kővel, ami természetesen csak akkor igazán érdekes, ha legalább ketten gyakorolják. A két fiút szokatlan módon hátulról fényképezték, ennek hátránya, hogy nem látjuk az arcot, viszont ennél jobban látható a fiúk jellegzetes életkoruknak megfelelő felsőteste, a kavicsdobálás jellegzetes kézmozdulataival. Sajátos a két fiú nyárias, rövidre nyírt tüskefrizurája is. A hullámzó víz a fiúk árnyékával egyfajta idillikus állapot, nyári és gyermekkori élmények aszszociálására csábítja a fotót szemlélőt. 


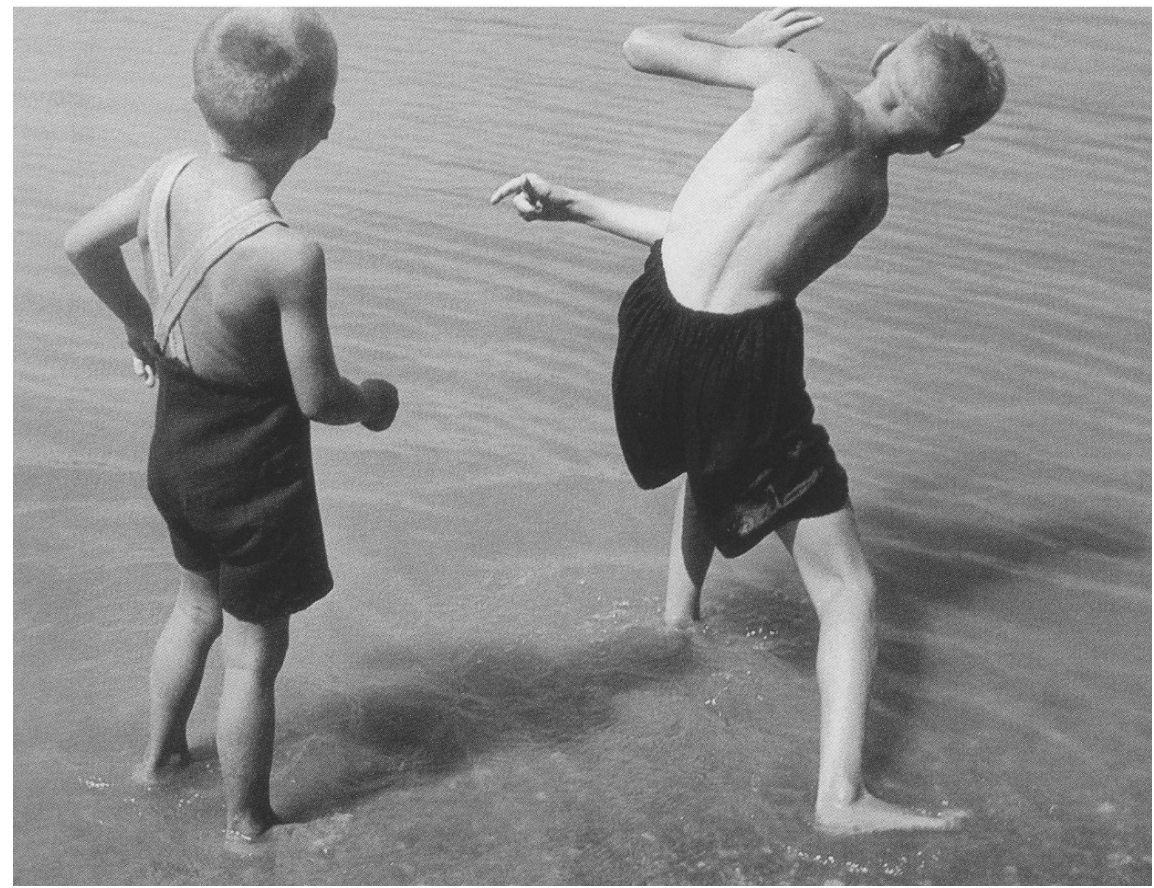

3. kép: A kavicshajítók (1934, Lengyel Lajos)

A természetes játékokhoz tartozik télen a kozása, lányok leginkább a hógolyózás szenminden gyermek által kedvelt hógolyózás. A vedő alanyai ebben az időszakban, így őket következő fénykép egy falusi hócsatát ábrá- inkább megmosdatni szokták friss hóval, ami zol. A gyerekek feltehetőleg iskolából jöttek köztudottan a szépségápolás és az évelődés ki, bár a taneszközöket nem látjuk, de a ruha egyik lehetősége. Némelyik gyermeken eseterre utal, illetve az a tény is, hogy sokan van- len nagykabát van, láthatóan nehezen is moznak együtt. A falusiakra jellemző csoporto- dulnak benne. Ez arra is utalhat, hogy többen sulás - alvég-felvég - jelei is megfigyelhetők hordják az adott ruhadarabot vagy előre gona két szembenálló tábor esetében. A köztes dolkozva sokkal nagyobb méretüt vásároltak. csoport a nagyobb létszámú támadók előőr- A fekete ruha és a fehér hó kontrasztja sajátos sének tekinthető. A hócsata főleg fiúk szóra- hangulatot ad a fotónak.

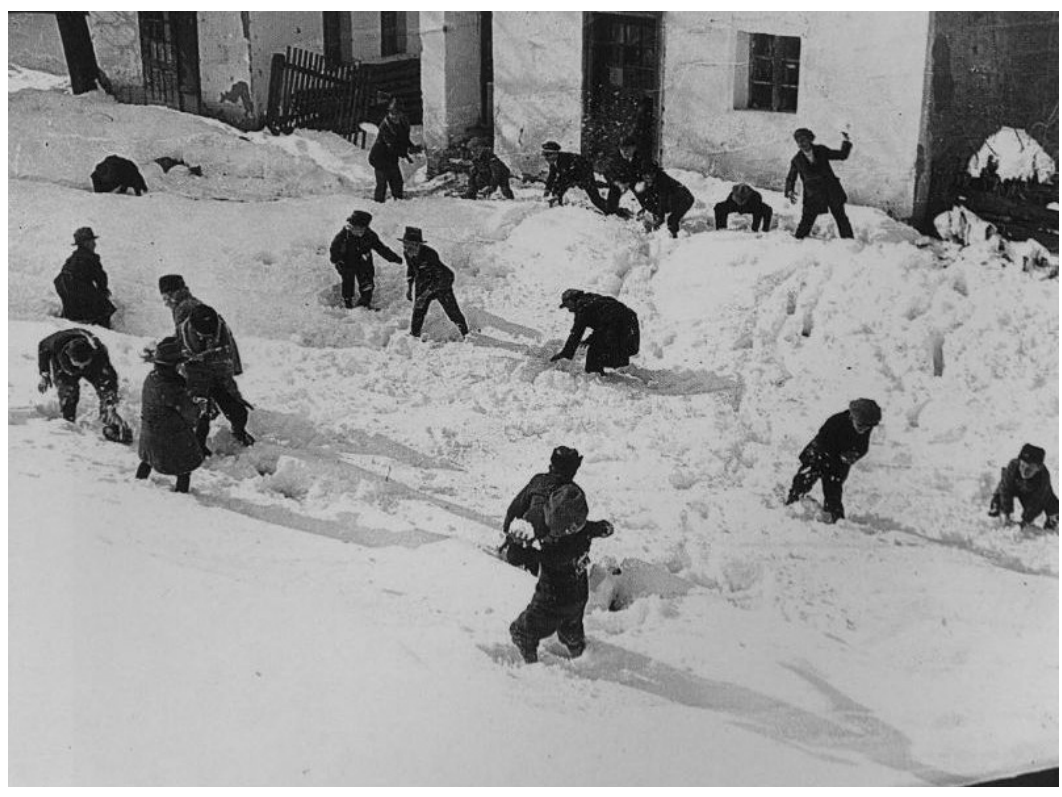

4. kép: Falusi hógolyócsata (1935, Balogh Rudolf) 
Ikonográfia és életképek a 20. század eleji Magyarországról

Természetesen, a játék jellegét tekintve vessző, szalma, kukoricacsuhé, kukoricaszár nagy különbség van a szociokulturális körülmények mellett a lakóhely jellegéből eredő hatásoknak. Mások a tanyasi gyermekek, a falusiak, a városiak és a nagyvárosiak életkörülményei. Az szomorú tény, hogy a nagyváros nyomortanyáin élők helyzete néha még a tanyákon élőknél is rosszabbra fordulhatott.

A szülők amennyire lehetett, igyekeztek lehetőséget teremteni a gyermekek játékigényének kielégítésére, főleg azért, hogy a gyerekek elfoglalják magukat és ne legyenek állandóan láb alatt. Többnyire a mindenütt megtalálható természetes alapanyagokból - fa, hajlékony

- készültek gyermekjátékok (Kiss, 2000). A játékkészítésben fontosak voltak a nagyszülők, különösen a nagyapák, akik ha kiöregedtek a mezei munkából, gyakran a maguk és unokájuk szórakoztatására - sokféle leleménnyel állatfigurákat, a kicsiknek terményből csörgőt, kis kocsit, kis széket faragtak. Veszőből sokféle kosárkákat és mindenféle más tárgyat készítettek. Erre példa az alábbi fényképen látható kerekes, kezdetleges, egyszerü, dísztelen járóka. A szép ruha, a kezdetleges eszköz és az altalaj egyáltalán nem harmonizál egymással. Sajnos a kép keletkezéséről nincs további információ.

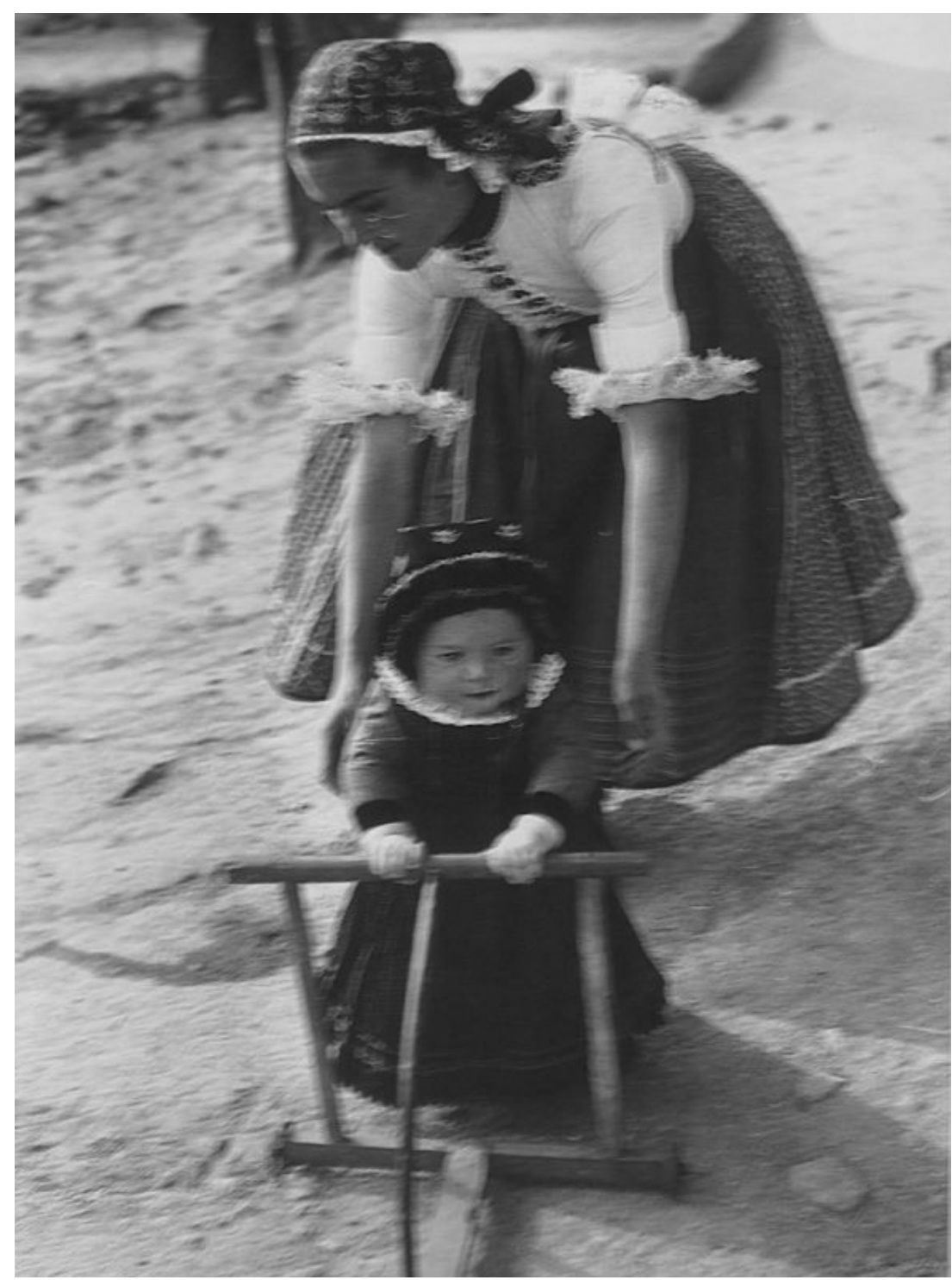

5. kép: Jár a baba, jár! (1939, Balogh Rudolf) 
Az iparos keresztszülők is gyakran ajándékoztak a gyermekeknek saját készítésű igényesebb játékokat, amilyen például a hintaló. A városban élő iparosok maguk igyekeztek gyermekeiknek játékokat készíteni. Az inasok gyakran kaptak olyan feladatot, hogy a szakma kezdő lépéseinek elsajátítását bizonyítandó, valamilyen játékos, néha viccelödésre lehetőséget adó eszközt készítsenek. A felnövekvő gyerekek maguk is igyekeztek játékokat készíteni. Minden magára valamit adó fiúnak illett saját magának elkészíteni bodzából a maga vízipuskáját, libatoll szárából a krumplipuskát. A karika hajtáshoz és az ostor készítéshez innen-onnan anyagokat kellett szerezni, bőrszíjat, sudárnak rafiát és meg kellett tanulni fonni is. A sokféle anyagból - szalmából, vesszőből, bőrből való fonás trükkjeit és mintáit el lehetett lesni az idősebbektől. A nagyobbacska fiúk búcsúfiaként gyakran kaptak bicskát, amit maguk fentek, élesítettek és ezzel megtanultak füzfasípot készíteni és faragni. Később - vizes környéken - mindenki maga készítette el a horgászfelszerelését és a fiús alapfelszereléshez tartozó parittyát is. A kislányoknak gyakran készítettek babaházat, ez sokszor öröklődött, fejlődött és időnkét törött is. A babaház gyakran kiegészült az idők során, felszerelése a vagyoni helyezettől függően gyarapodott. A kislányok gyöngyfüzéssel, varrással, szövetanyagok feldolgozásával, gyüjtögetéssel és gyüjteményük rendszerezésével töltötték az idejüket. Kedvenc játékaik közé tartozott a csoportosan élvezetes ugróiskolázás és ugrókötelezés, a karikás gyakorlatok sokféle variációja, de legkedvesebb elfoglaltságuknak mégis a hintázás tekinthető. A fiús-lányos játékok elkülönülése a valós életben nem ilyen merev, a gyerekek bátran használják egymás játékait is. Az alábbi fényképen ennél rosszabb élethelyzetbe pillanthatunk be. Itt szinte életveszélyesen elhanyagolt környezetben kell a gyermekeknek feltalálniuk magukat és a csupasz földdel játszanak, talán alagutat vagy hidat építve.

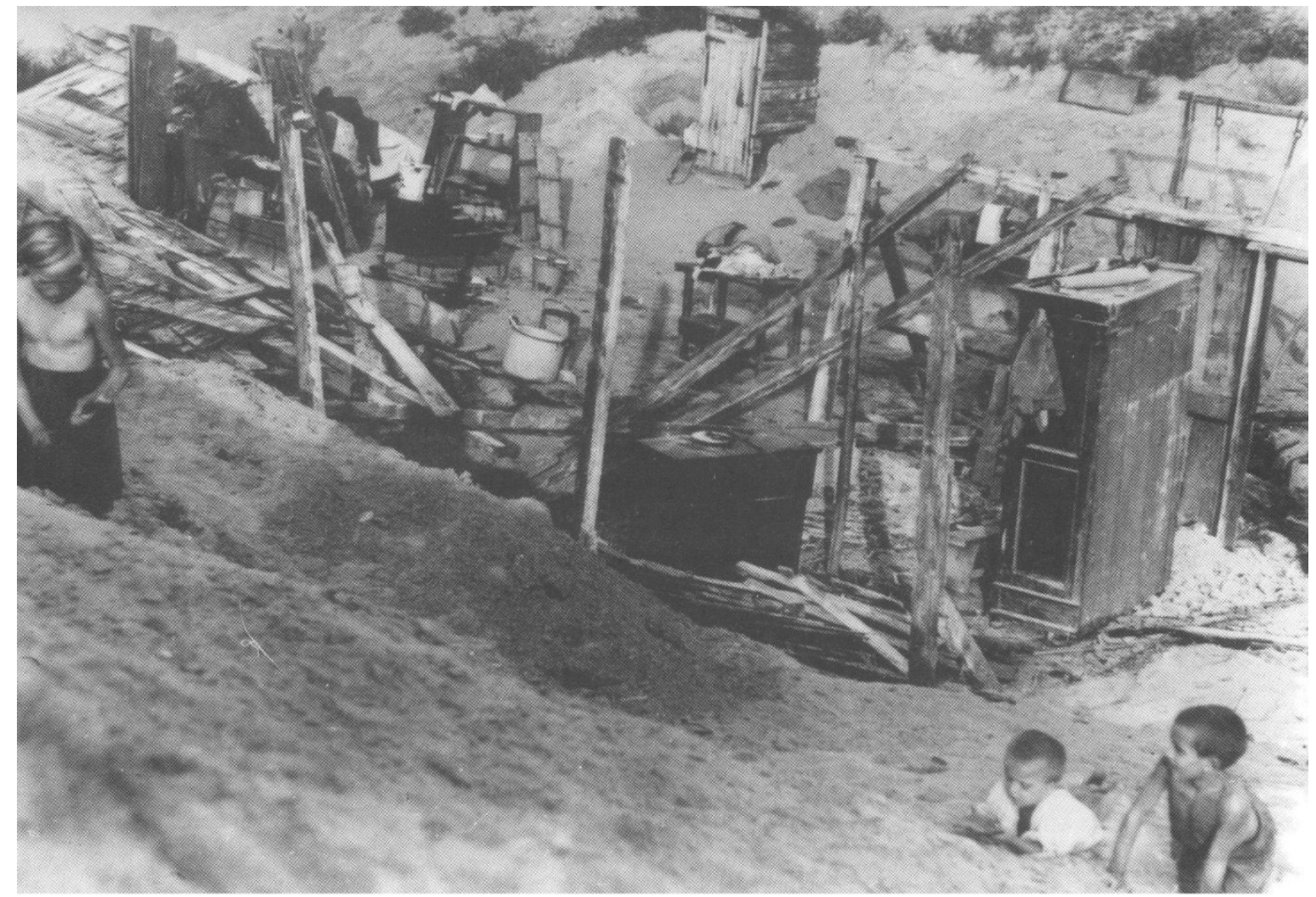

6. kép: Játszó gyermekek a Hangyatelepen (1931-1932, Frühof Sándor) 
Ikonográfia és életképek a 20. század eleji Magyarországról

Ugyancsak homokkal játszik ez a másik tum is láthatóvá válik, ami nem más, mint a kisfiú is, de az előzőektől eltérő környezetben gyermekek másik kedvenc vízparti szórakoa Maros partján. Ebben az esetben a produk- zása - a várépítés.

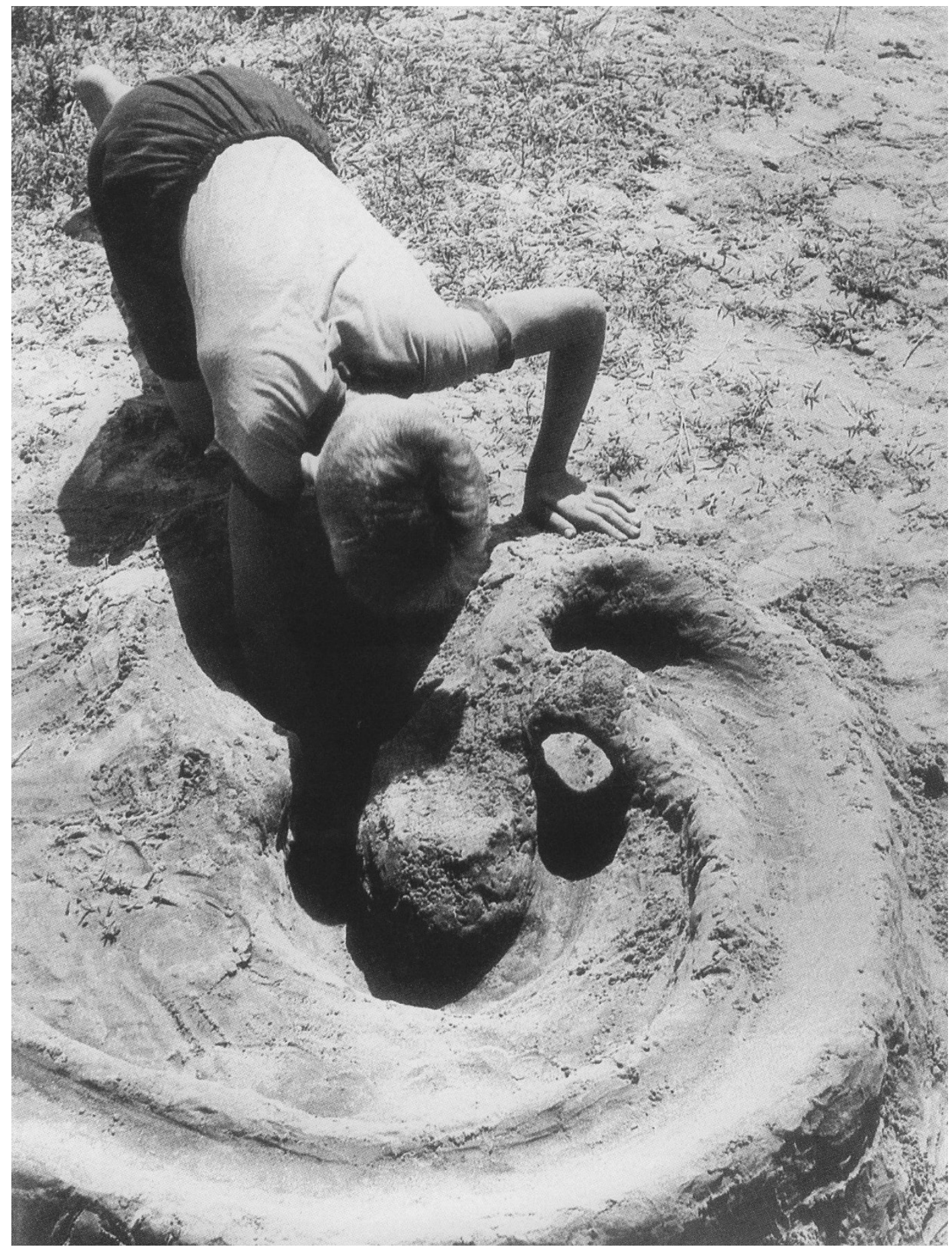

7. kép: Maros-parti kisfiú (1934, Lengyel Lajos)

Propagandisztikus célt is szolgált 1919- utolsó pillanatokat mutatja, a kísérő szülők és ből a Tanácsköztársaság idején a gyermekek talán testvérek ruházata nem a legszegényebb nyaraltatásáról tudósító felvétel. A téma tipi- proletárokra, hanem inkább az alsó középkusan - a jól ismert, a vonat indulása előtti osztályra utal. 


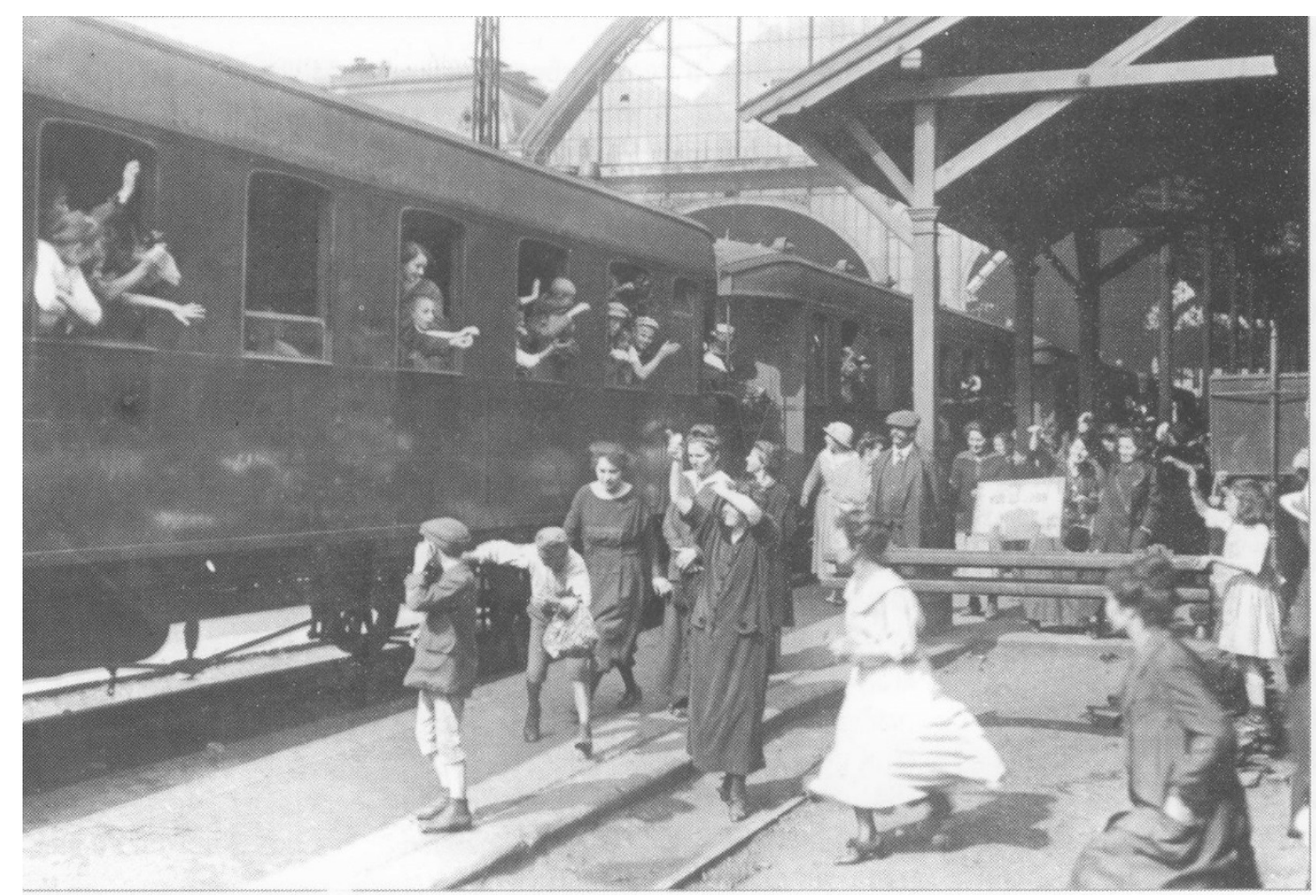

8. kép: Nyaralásra induló proletárgyerekek (1919, Müllner János)

\section{Jól szituált gyermekek életkörülményei}

Kezdésként egy fényképsorozatban Vértes Gyurikát láthatjuk 2, 4 és 5 éves korában, így vizuálisan követhetjük nyomon egy polgári környezetbe született gyermek fejlődését. Jelen esetben műtermi, tehát beállított fotókról van szó. Vértes Gyurika mind a három fotón nagyon vidám, magabiztos, a megilletődöttség nyoma sem látszik rajta. A Mai Manó műterméből származó képeken a háttérként szolgáló tárgyak kevésbé fontosak, inkább kompozíciós jelentőségük van, ahogy ezt a kétéves gyermek iskolai táblával történő ábrázolása is tanúsítja. Gyermekkortörténeti szempontból viszont figyelmet érdemel a gyermek ruházatának és hajviseletének a megfigyelése. Ebben egy szempont lehet a fiús és lányos részletek elkülönülése vagy egy-egy részlet megjelenése a másik nemnél is.
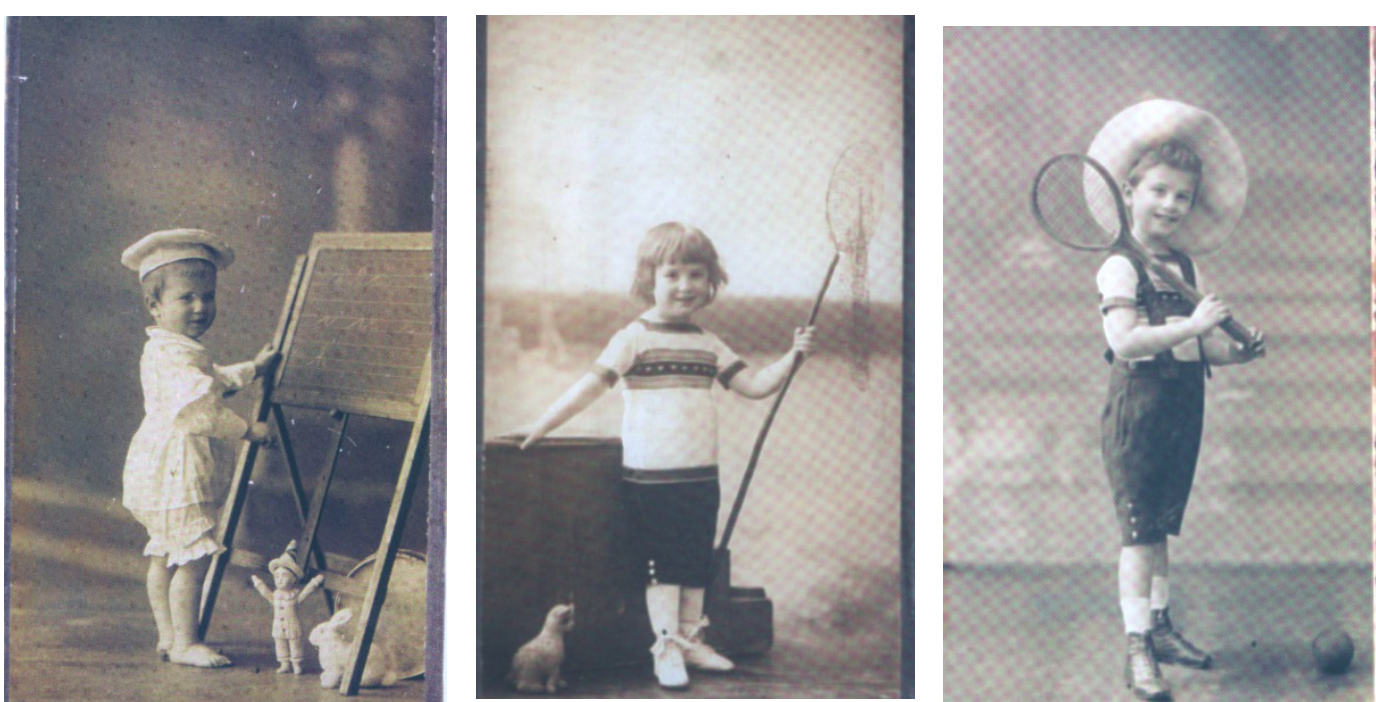

9-11. kép: Vértes György 2, 4 és 5 évesen (XX. sz. eleje) 
Ikonográfia és életképek a 20. század eleji Magyarországról

Az alábbi fotók gazdag polgári, illet- ül, direkt erre a célra készült babaszéken. A ve arisztokrata család kislányát ábrázolják. másik fotón az elegáns ruha biztosítja az exkMindkét fotóra jellemző a túlzás. Az első fo- luzív jelleget és a nélkülözhetetlen teniszütő, tón nem egy, hanem három drága hajas baba amelyet még két labda is kiegészít.
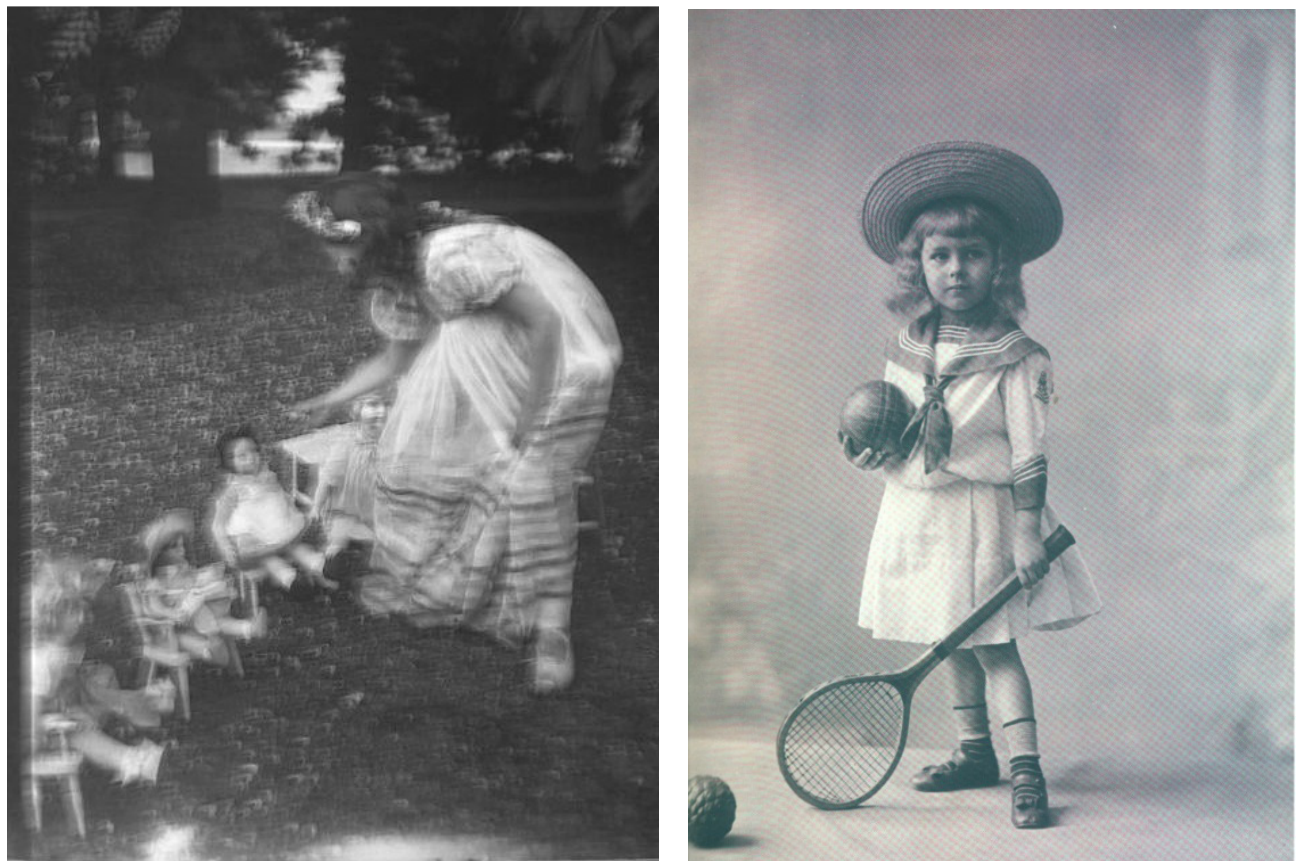

12-13. kép: Babázó kislány (1935, Balogh Rudolf); Baron Jeszensky (1905, Mai Manó)

Az első áldozás a gyermekek életében kitün- ezért erről viszonylag bőséges források állnak a tetett történés, mert ettől kezdve egyházi szem- kutatók rendelkezésére. Ezúttal egy jómodú polpontból már hozzájárulhatnak a szentségekhez. gári családból származó kislány és egy hasonlóEzt igyekeztek minden családban megörökíteni, an jómodú testvérpár fotója kerül bemutatásra.
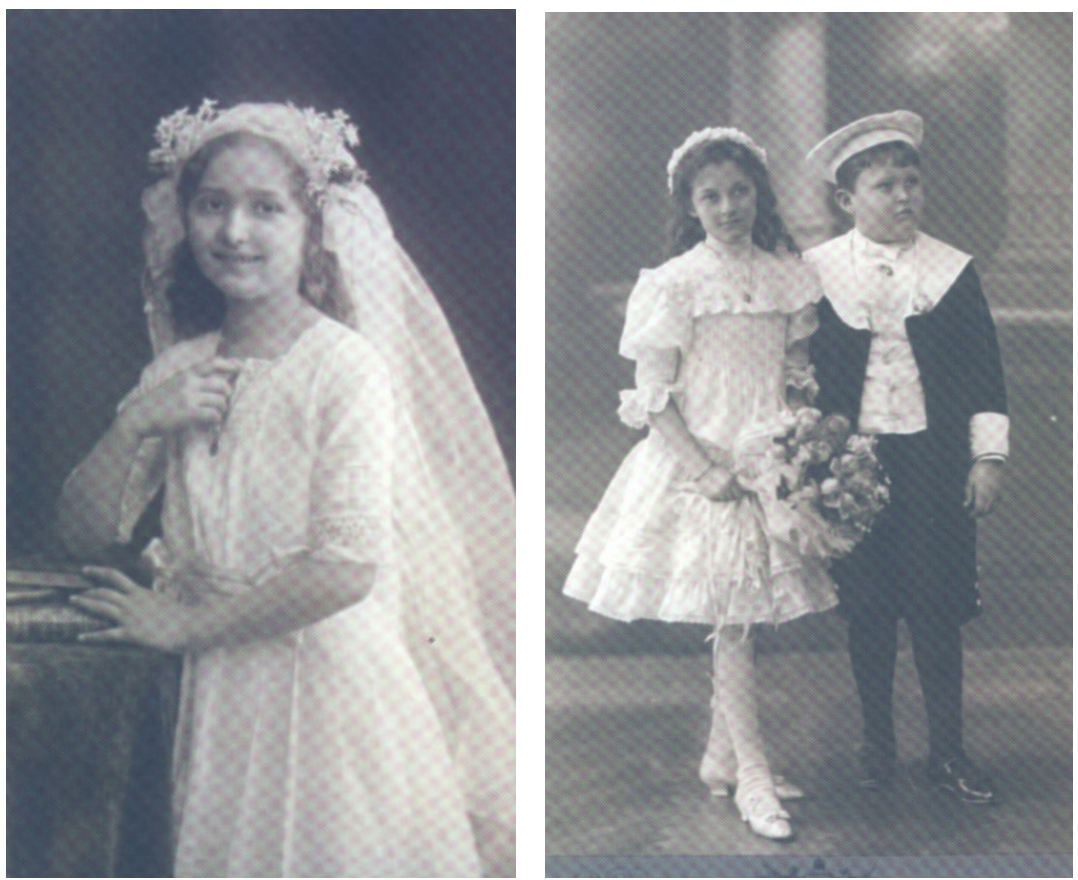

14-15. kép: Elsőáldozó leány (1905, Mai Manó); Elsőáldozó testvérpár (1905, Mai Manó) 
Fiúportrék estében a leggyakoribb a puskával, dobbal, teniszütővel történő ábrázolás, kivételesen előfordul egy-egy szellemi műveletet középpontba állító ábrázolás is, ilyen az olvasó fiúk portréja.

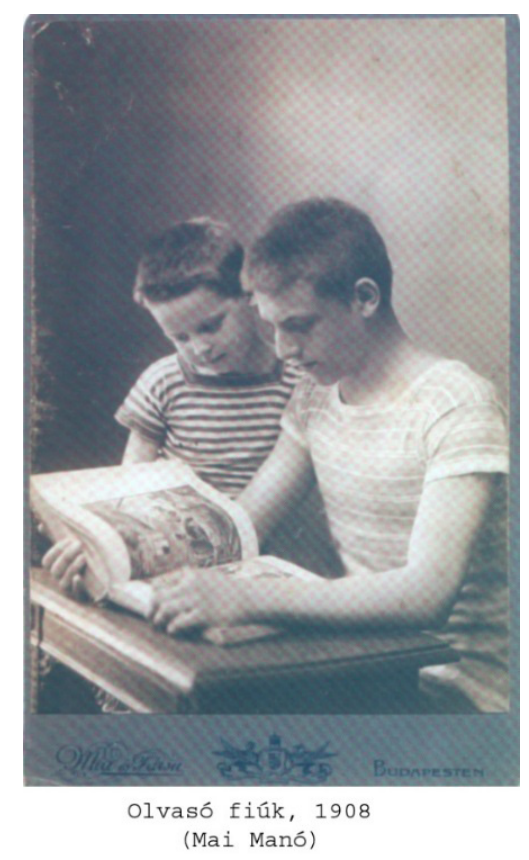

16. kép: Olvasó fiúk (1908, Mai Manó)

\section{Önálló kép - dada gyermekkel}

A következő tematikáját tekintve ritka, de előzőeknél korábban keletkezett fénykép kisgyermeket ábrázol a dadájával. A dada viszonylag fiatal asszony, a kezén is lehet látni, hogy talán a nehéz fizikai munkától meg van kímélve. A mütermi fotón mégis van valami szokatlan, ezt egyrészt mindkét arc merevsége adja, másrészt az a furcsa helyzet, hogy a dada és a kisgyermek nem egymásra néz, a kisgyermek keze is össze van kulcsolva és nem a dadáját öleli át, ahogy ez várható lenne. A fotó készítésének körülményeit csak találgatni lehet, mert viszonylag ritka, hogy a dadával készítenek fotót. Ebben az esetben a fotó ellentmond az életrajzi narratíváknak, ugyanis az esetek többségében nagyon meghitt, szép emlékek, meleg érzések füződnek a dadához.

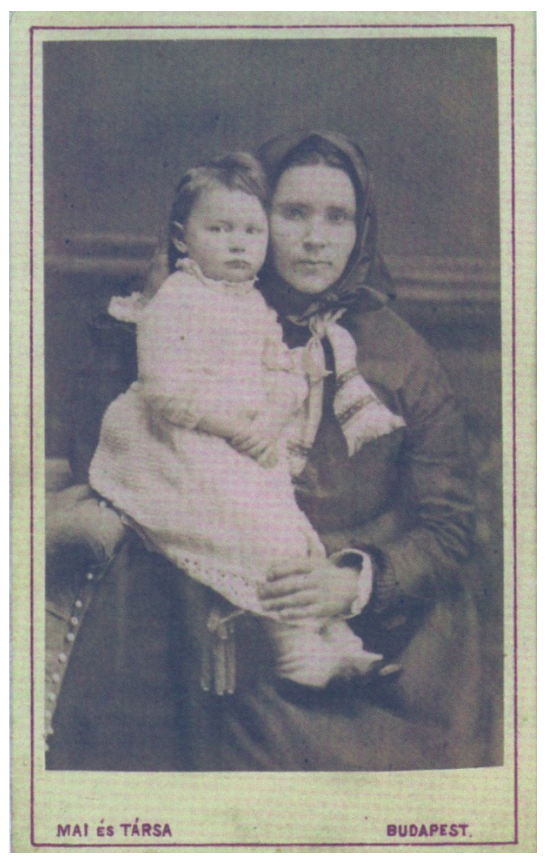

17. kép: Dada gyermekkel (1879)

\section{Egy gyakori téma - ételosztás}

A nagyvárosi életmód messze nem mindig jelent jólétet, ahogy erről az alábbi ételosztásról tudósító fénykép árulkodik. Az ételosztásra egyébként előszeretettel küldenek gyermekeket, egyrészt mert a felnőttek szégyellik, másrészt abban bízva, hogy a gyermekek több ételt kapnak. A két különböző élethelyzetű gyermek - ami a ruházatuk alapján is megállapítható - láthatóan elégedett a kapott étellel, azért bele-belekukkantanak a másik fazekába, miközben nagyon óvatosnak kell lenniük, nehogy kiloccsanjon az étel. Az ételosztás rendjére ügyelő egyenruhás férfi sajátos hangulatot ad a fotónak. A héttérben álló idősebb fiú szemében pedig valamiféle vágyakozás látszik. Az utcakövek egyenetlen mintázata és a repedések is erősítik a fotó vizuális hatását, talán valamelyest utalva a társadalmi egyenlőtlenségre is. 
Ikonográfia és életképek a 20. század eleji Magyarországról

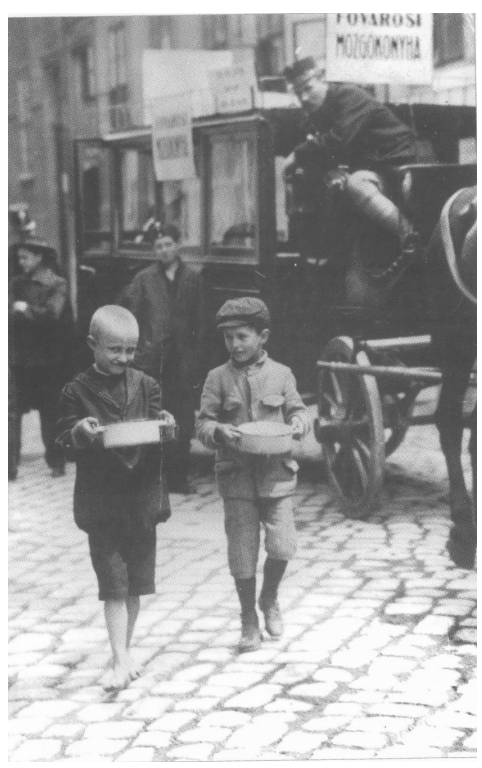

18. kép: Ételosztás, Bp. (1910, Müllner János)

Ez a téma jelenik meg egy korabeli, igazi ritkaságnak számító fotón, ugyanis iskolába, pontosabban egy napközi otthon életébe pillanthatunk be egy képsorozat keretében, igaz nem tanulás közben, hanem az ebéd előtti várakozást figyelhetjük meg. A jól öltözött városi gyerekek és a polgári ruhát viselő felügyelö, valamint a gyermekek elhelyezkedése leginkább szolid jólétről, nyugodt várakozásról árulkodik. Itt bizonyára nem kell megküzdeni minden falatért - eltérően a korábbi képektől - mert mindenkinek jut elegendő étel. Néhány diák hóna alatt ott vannak a taneszközök, köztük könyvek, füzetek és - talán a fiúk számára harci eszközként is használatos - fejes vonalzó.

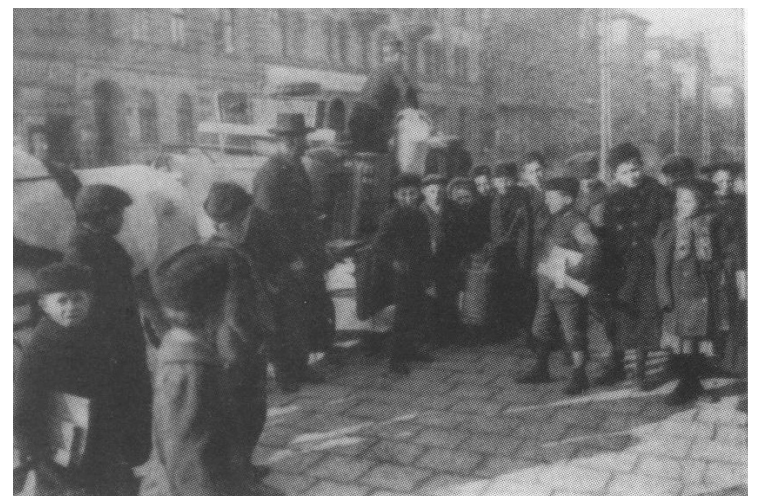

19. kép: Napközi otthon, Bp. Az ebéd megérkezik (1908, Balogh Rudolf)

A kisméretü - napközi otthoni mosogatást ábrázoló fotón - jellegzetes iskolai bútorzatot látunk, ilyen a sarokban álló öntöttvas kályha, a kecskelábú asztal és a mosogatás céljára szolgáló dézsa, továbbá az asztal alatti vizes kanna. A szegényes és igénytelen berendezésre utal a sima, díszítés nélküli háttér és főleg az a tény, hogy a gyerekek a földön guggolva dolgoznak. Az asztal mögötti fiatalember státusza - pedagógus-e vagy pedellus - nem állapítható meg, mindenesetre a gyerekekkel szembeni távolságtartása kiérezhető a fotóból. A rend valamilyen szintű igényét sugallja a háttérben álló rendezett, edényeket tartalmazó polc és az asztalon összerakott tányérok, valamint a mellette álló nagyobb lábos. Valószínűleg a fekete mosogatást a földön ülők végzik, az öblítés és a szárazra törlés pedig az asztalon történik.

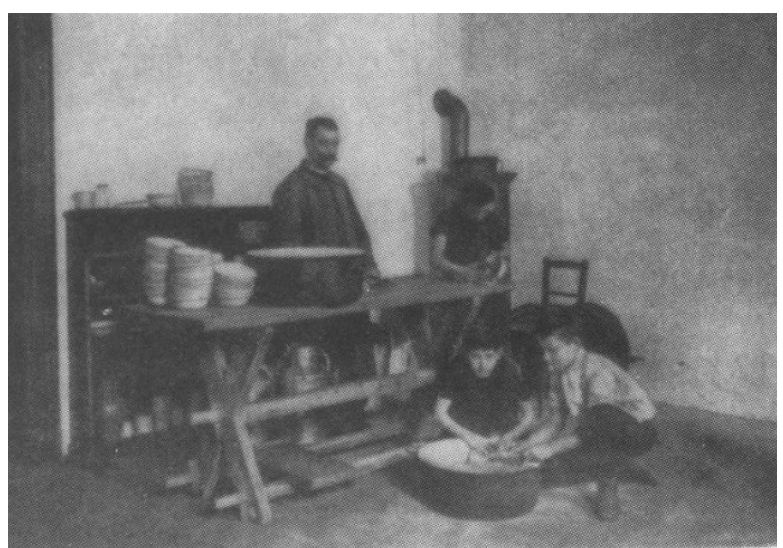

20. kép: Ebéd után a napközi otthonban, Bp. (1908, Balogh Rudolf)

Hasonló témát dolgoz fel a következő fotó is. Jellemző módon alig találni iskolai oktatásra, tanórára vonatkozó fotót erről az időszakról, annál többet az étkezéssel vagy annak hiányával kapcsolatban. Az ebédelő gyermekek láthatóan jóizűen fogyasztják ételüket, a parasztemberek módszeressége látszik abban, ahogy tartják a kanalat és főleg abban, ahogy a kenyérrel bánnak. Maga a szép vastag szelet kenyér az étkezés fontos és megbecsült részének látszik. Az első fiú csak ízlelgeti, a középpontban álló már beleharapott, a háttérben látható gyermek pedig későbbre hagyta a jó minőségü, lyukacsos, tehát kelesztéssel készült kenyeret. 


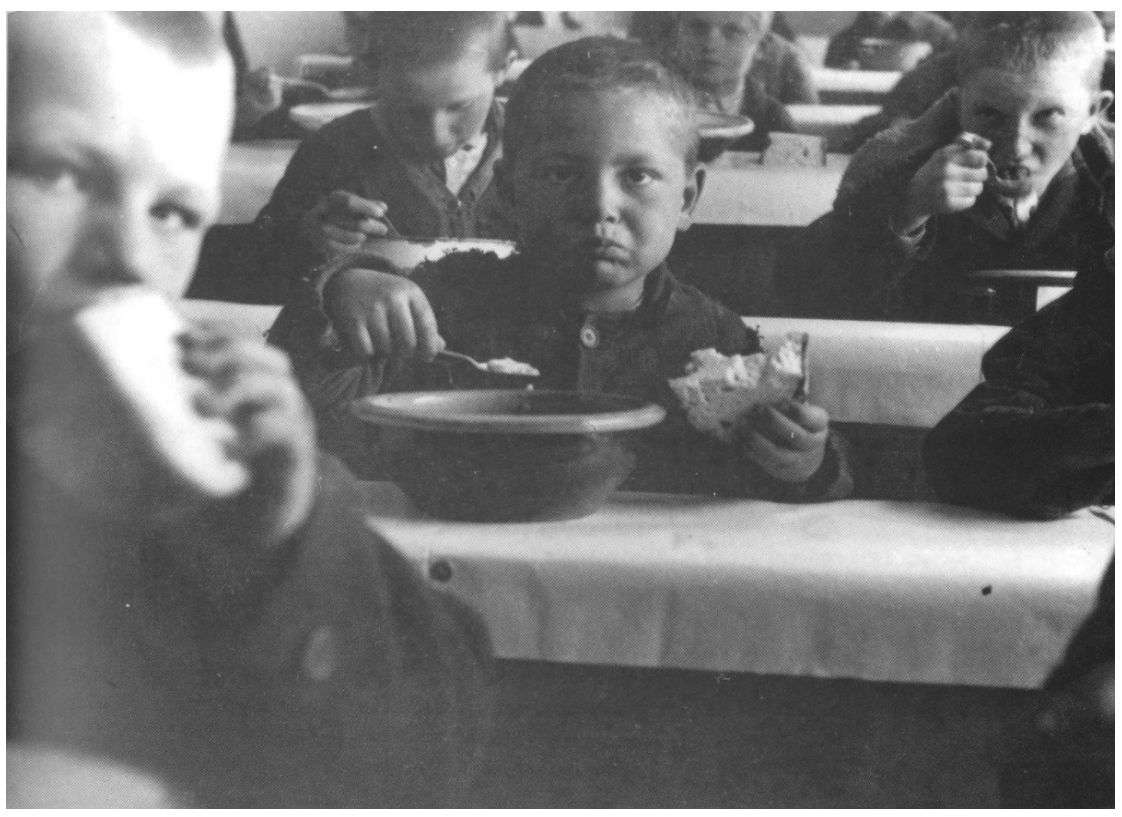

21. kép: A kötönyi csoda (Lakatos Vince)

Akinek nem jutott étel, az kénytelen volt amire a hátul álló szakácsnő vagy ételosztó elmenni az ínségkonyhára, ahol bizony hosz- pozíciója is utal. Egy pontra koncentrálódó szadalmas várakozás után, csak némi sze- tekintetekből árad a várakozás feszültsége, rencsével lehetett valamiféle ételhez jutni. A amelyet még tovább erősít a kézben tartott sok-sok összecsukott száj, a várakozó, mosoly edények váltakozó tartása, némelyik lefelé nélküli tekintetek, az üres edények és főleg fordítása, vagy az üres tányérba helyezett kaa jelenlevő sokaság nem sok jóval kecsegtet. nál és főleg a tágra nyitott szemek és komor A várakozás bizonyára még eltart egy ideig, tekintetek éhségre utalnak.

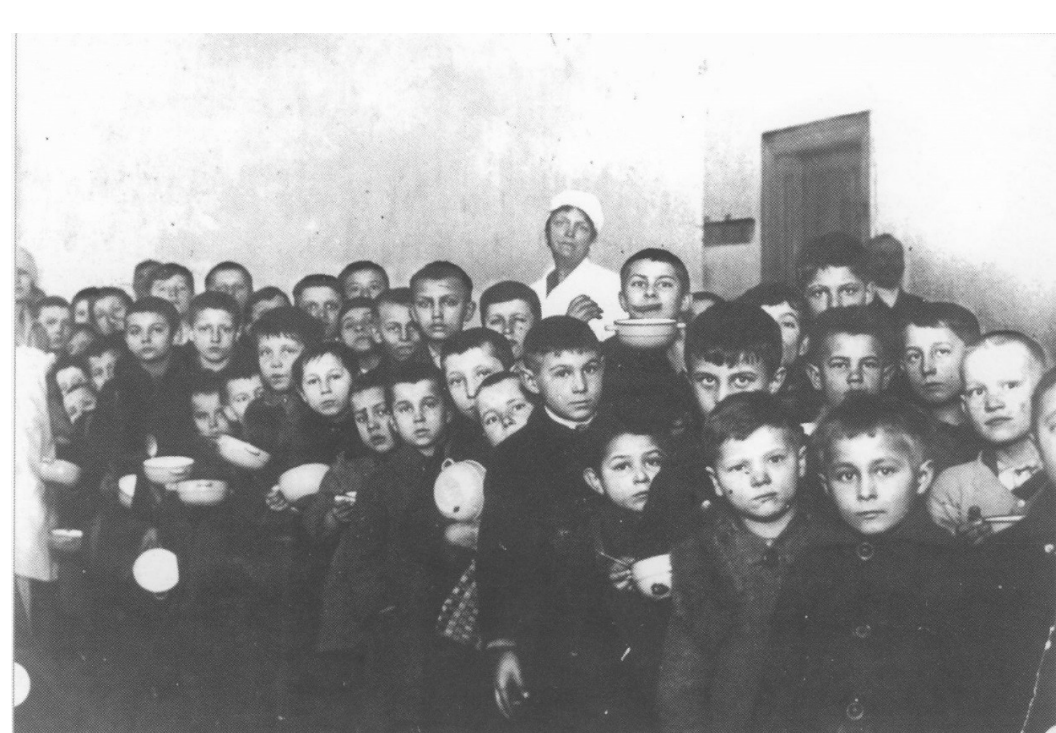

22. kép: Ínségkonyha (1930, Gyagyovsky Emil) 
Ikonográfia és életképek a 20. század eleji Magyarországról

\section{Önálló kép - iskolai fütéshez fahordás Gyermekmunka mint motívum}

Az iskolai élet tematikájához tartozik egy másik ritka, feltehetőleg reklámcélra készített fénykép, amelyik azt a korabeli szokást szemléleti, amikor a gyerekeknek az iskola fütéséhez naponta egy-egy fahasábbal kellett hozzájárulniuk. Ahogy az egyébként jól öltözött gyerekek vidám arccal, szinte tüntetőleg mutatják a magukkal hozott, nagyon is egyformának látszó fahasábokat, ez megerősíti azt a feltevést, hogy ez egy megrendelésre készült beállított fotó.

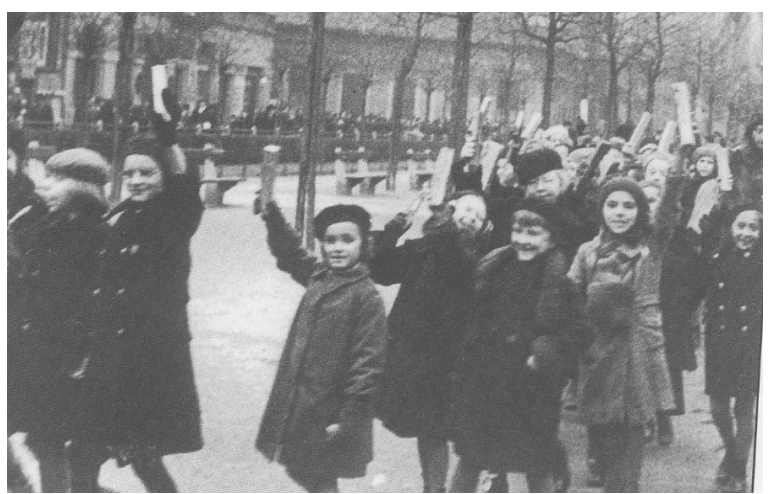

A falusi gyermekek életében már korán megjelenik a munka - a ház körüli segítés vagy éppen a szülő foglalkozásába való fokozatos bevezetés formájában. Ennek nagyon szép példája az erdélyi fafaragók tevékenységét bemutató fénykép. Már gyermekkorban is vannak olyan feladatok - jelen esetben a hasító fejsze tartása - ami komoly segítség a szülőnek. A fénykép természetességről, magabiztosságról és odafigyelésről tanúskodik, mindkét fél részéről, hiszen nagyon egyszerű körülmények között, nagyon balesetveszélyes munkát végeznek. Jelen esetben a háttér, a vastag falakkal, a zsindelytetővel rendelkező ház és a falnak támasztott husángok, illetve szerszámok, a rendezetlenség ellenére valamiféle biztonságot sugallnak.

23. kép: Hozz egy darab fát (1937, Inkey Tibor)

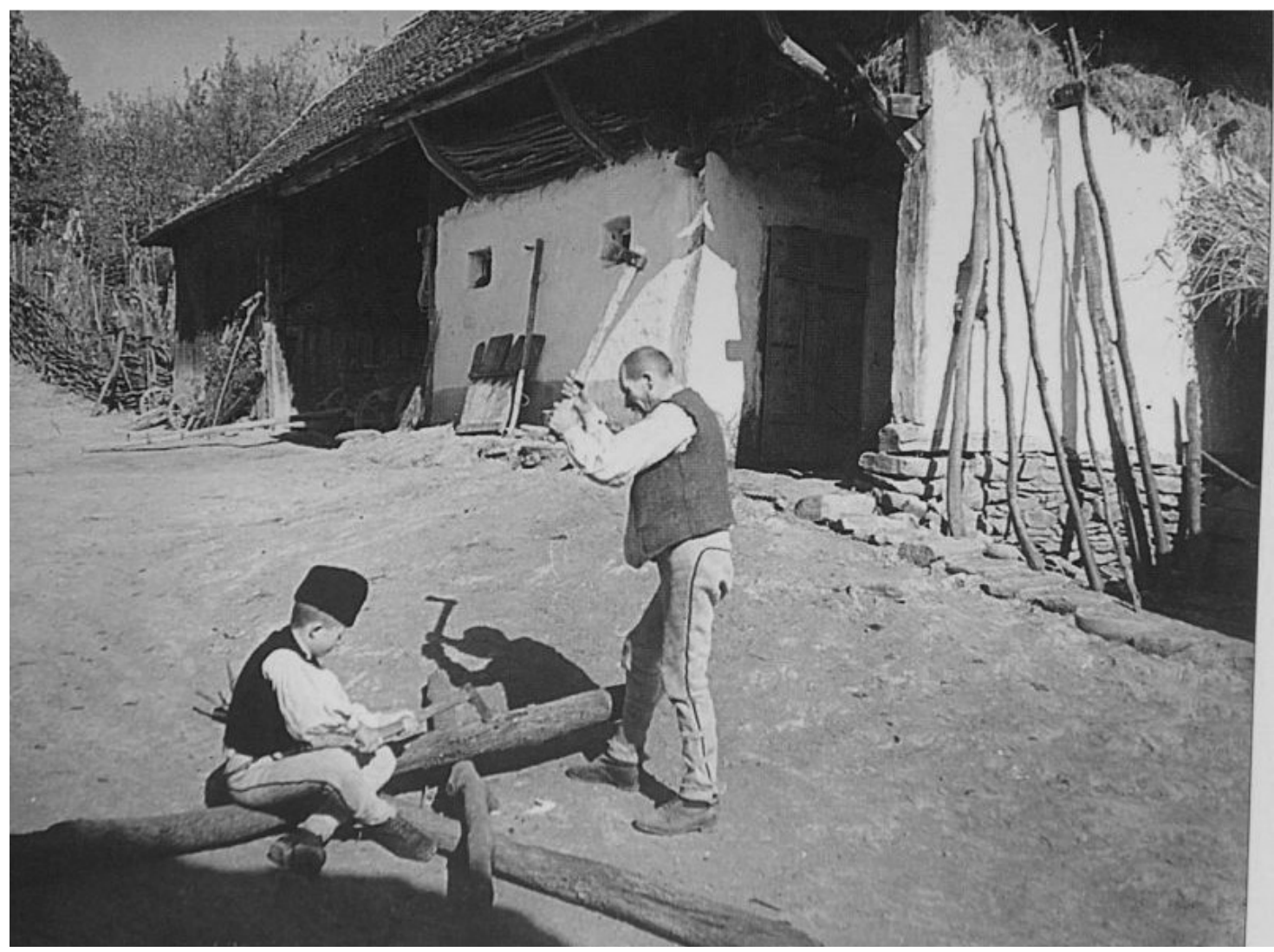

24. kép: Favágás az udvaron, Erdély (1940, Balogh Rudolf) 
Kislányok gyakran kapták feladatként háziállatok legeltetését, ami a korántsem egyszerű feladat hiszen meg kell tanulni az állatok terelgetését, aminek fontos része, hogy fel kellett ismerni az állatok között a vezéregyéniséget. Továbbá fontos ismerni a határt és a növényeket, nehogy idegen helyre tévedjen az állatsereglet. A legeltetést végző személynek tisztában kell lenni a ragadozók - héja, róka stb. - szokásaival és meg kell védenie a rábízott állatokat. Kislányok számára gyakori feladat a sokféle házimunkában való segítés. Ennek legegyszerübb módja a vízhordás, de ez sem egyszerü, különösen, ha a kútnál kannába kell merni a vizet és azt meg is kell tartani, nem is szólva arról, hogy a súlyos kannát a helyére kell vinni. Már maga az egyszerű tűzgyújtás és a kályhák, kemencék sokféle formájában, a tűz fenntartása és a megfelelő hőmérséklet biztosítása sem könnyủ feladat.

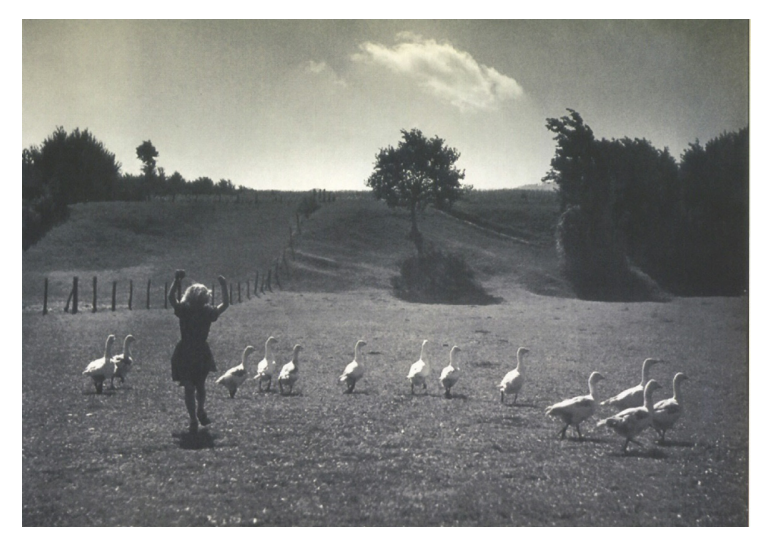

25. kép: Libák (1939, Rév Miklós)

Vannak különösen komoly szakértelmet igénylő feladatok, ilyenek például a faszenes vasalóval végzett műveletek, amelyeknél kipattanó szikra esetén könnyen a ruhadarab maradandó károsodása következik be. Hasonlóan komplikált művelet a nagymosás, amit jelen esetben a folyóparton végeznek. A szép fehér ruha többféle szigorúan egymás után következő művelet - így az áztatás, sulykolás, öblítés - eredménye. A tevékenység monotóniáját csak részben csökkenti, hogy általában azonos időben többen is végzik ugyanezt a tevékenységet.

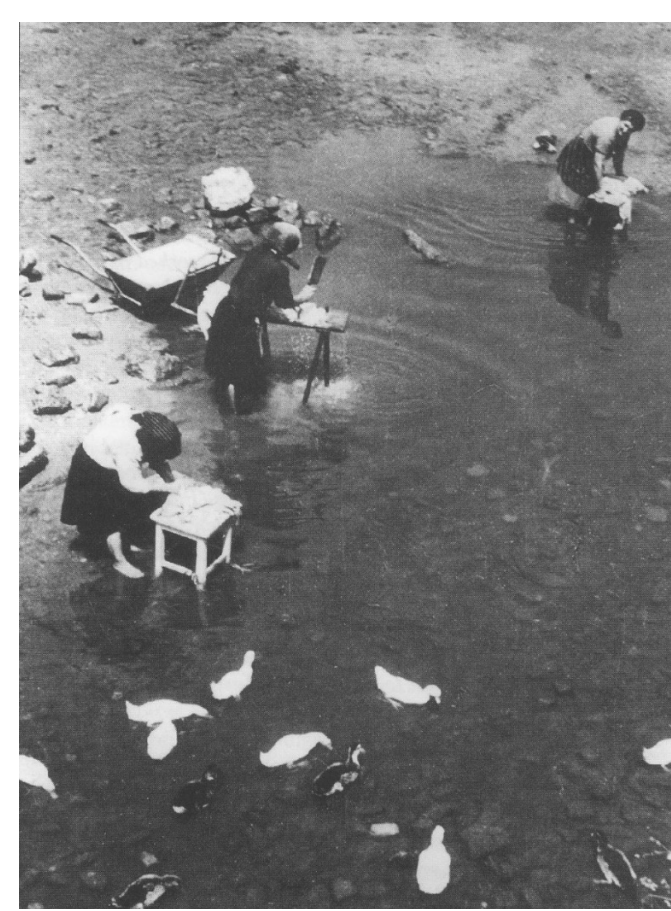

26. kép: Mosás a pataknál (1932, Inkey Tibor)

A gyerekek segítsége fontos a mezőgazdasági munkában is, ahol az egész család öszszefogására van szükség a boldoguláshoz. A szegényebb családok az ekevontatásra alkalmasabb ökrök vagy lovak helyett kénytelenek tehenekkel szántani, ilyenkor pedig elkel a teheneket vezető segítő gyermek.

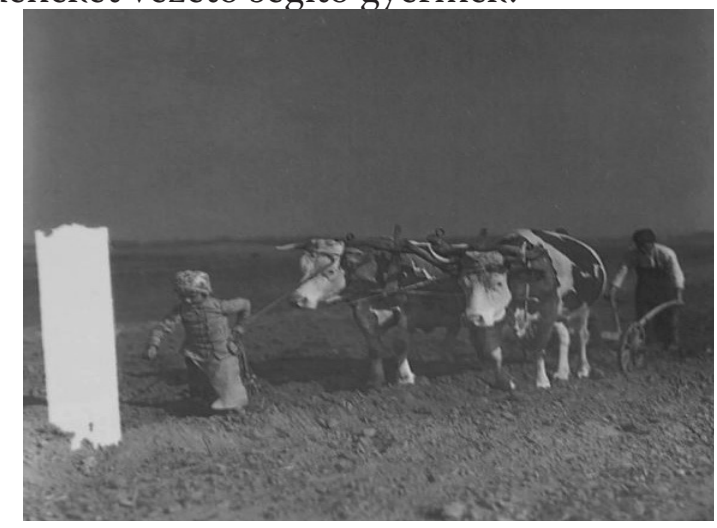

27. kép: Szántás tehenekkel (1936, Balogh Rudolf)

Városi gyerekek számára más elfoglaltságok adódnak, ezek közül a legjellemzőbb a bolti kisegítés küldöncként. Az ő feladata az áruk eljuttatása a megrendelőkhöz, de mindenféle más munkába is bekapcsolódhatnak. Természetesen vannak kivételesen jó kapcsolatokkal rendelkezőknek kivételes lehetőségek, ilyen például a kugliállítás a kocsmákban, ami jól jövedelmez, de hasonlóan szép feladat 
a focisták vagy a teniszezők közelébe kerülés is, kezdő lépésként labdaszedőként, amelyet az alábbi fénykép örökített meg. Labdaszedőnek lenni komoly karrier a gyermekek között, hiszen akármilyen csekély szerepben, de mégis a sportolók közösségéhez tartozik. Sok későbbi sportoló karrierjének a kezdete a labdaszedői feladat ellátása volt.

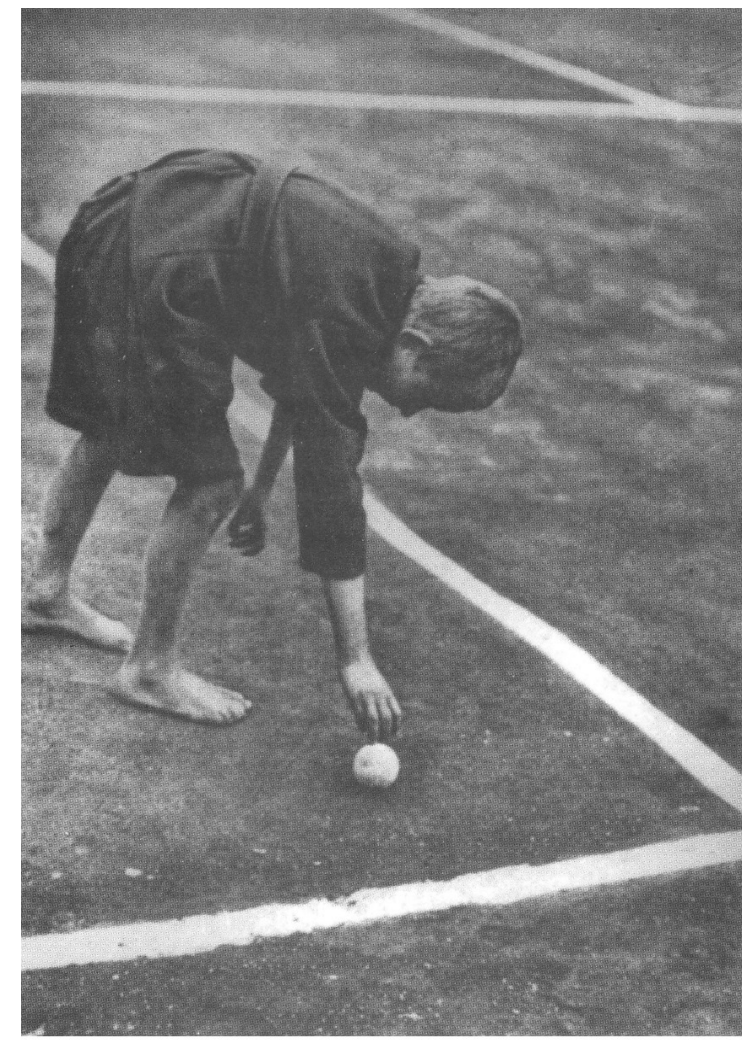

Labdaszedő gyerek, é. n. (Frühof Sándor)

28. kép: Labdaszedő gyerek (é.n., Frühof Sándor)

\section{Sajátos élethelyzet - gyermeki tragédiák}

A tematikát a sajátos élethelyzetű gyermekek ábrázolása teszi teljessé. Az első fotón olyan alvó gyermekeket látunk, akik nem ágyban alszanak. A kisebbeknek egy ládán ágyaztak meg és egy közös takarójuk van. A nagyobbaknak már csak a földön jut hely, talán szalmazsákon vagy ruharabokon ágyazva meg, és a klasszikus nagyon szegény körülmények között élők gyakorlata szerint szorosan fekszenek egymás mellett.

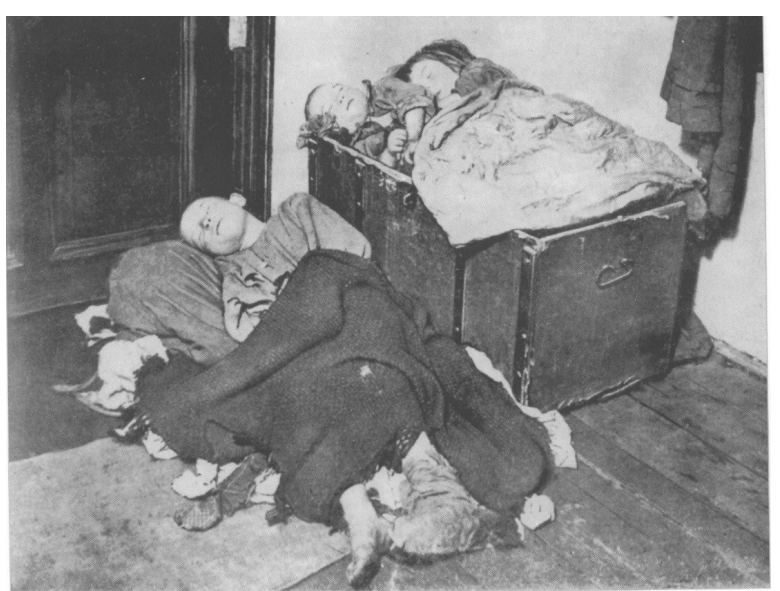

29. kép: Gyermekfekhely, (1920, Tábori Kornél)

A legtragikusabb, ami egy családban történhet, az a gyermek halála. A gyermekhalandóság a múlt században nagyon sokszor előfordult, különösen kis korban torokgyík és más betegségek miatt. A rossz lakásviszonyok, a nem kielégítő táplálkozás és következményei nyomán a múlt század elején a megszületett gyermekek több mint fele meghalt (Pirka, 2010).

Egy gyermek temetését ábrázolja a következő nagyon szomorú fénykép. A gyermekhalál viszonylagos gyakorisága miatt elsősorban a szülők és a közeli rokonság ügye, ezért leginkább a gyors léptekkel haladó legközelebbi hozzátartozók vesznek részt az egyszerű temetésen. A kopárnak látszó tájon haladó magányos kocsi és a gyászolók kocsitól távolabbi menete végtelen szomorúságot áraszt, amit még kiemel a kanyargó út is.

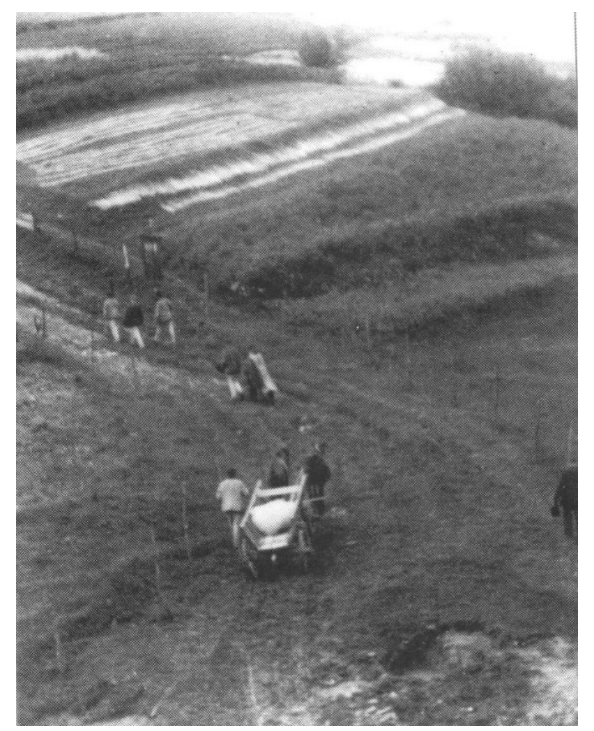

30. kép: Gyermektemetés Verhonán (1930, Földi Rózsi) 
A gyermekekre a betegségeken kívül nagyon sokféle veszély leselkedik, a törvényszerű törések-zúzódások az élet természetes részének tekinthetők, de vannak másféle komoly veszélyforrások is. Ilyen gyakori sérülés a leforrázás, a mosáshoz használt lúgból ivás, a vízbe fulladás és a valamilyen gödörbe történő beleesés. Az alábbi fénykép éppen egy felnőttek és gyerekek életében is gyakori halálozási okot, a kútba fulladást mutatja. A fénykép egésze a tehetetlenségre utal, a háttérben álló fehér ruhás egésszégügyisnek már nincs teendője, a hatóságot képviselő férfiak pedig tétlenül állnak a kútba fulladt gyermek mellett.

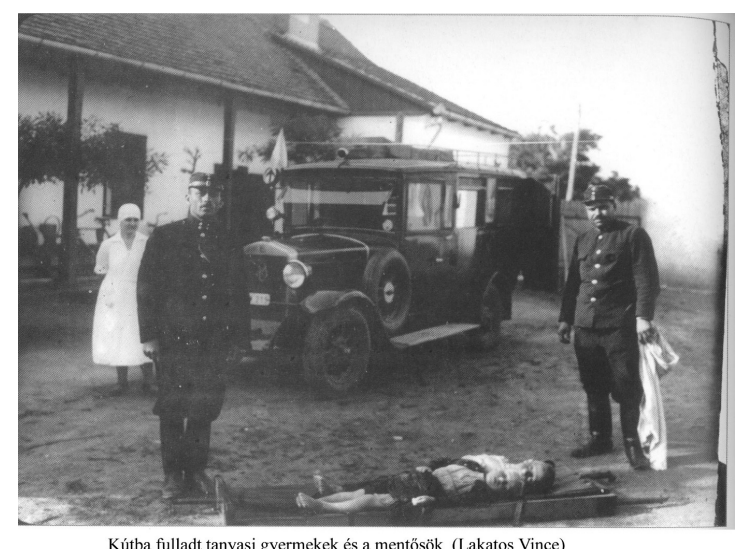

31. kép: Kútba fulladt tanyasi gyermekek és a mentősök (Lakatos Vince)

\section{Önálló kép - muzsikáló cigánygyermekek}

Földi Rózsi alábbi fotóján falusi gémeskút körül álló cigánygyermekeket látunk. A gyermekek ruházata nem más, mint a többi falusi gyerek hétköznapi öltözete. Fontos megkülönböztető jelzés viszont az, hogy mindegyikük kezében ott a hegedű, utalva későbbi kenyérkereseti lehetőségeikre. A két kisebb gyermek viszont még tisztes távolságból figyeli a nagyobbakat

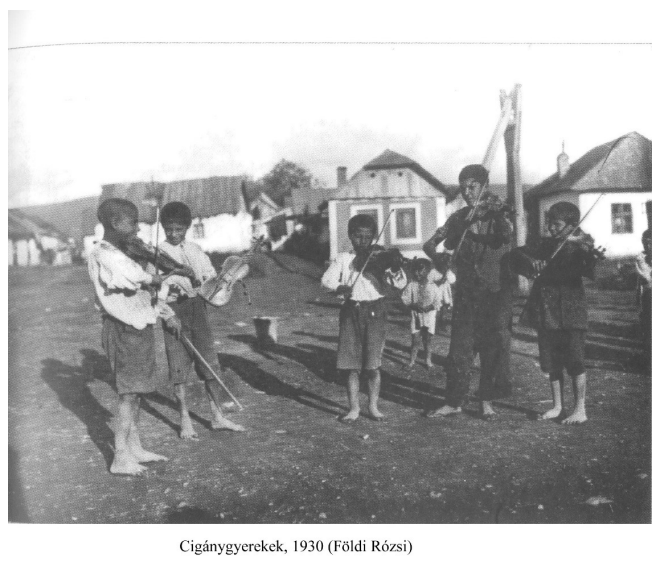

32. kép: Cigánygyerekek (1930, Földi Rózsi)

\section{Önálló kép - zsidó gyermekek}

A zsidóság magyarországi helyzete önmagában is összetett sorskérdés. Életmódjukat sok tekintetben befolyásolta, hogy országokon keresztüli üldözöttként kerültek-e az országba, vagy már tartósan itt éltek megfelelő egzisztenciát teremtve maguknak. Élethelyzetüket befolyásolta még az is, hogy nagyvárosban vagy kisebb helyen telepedtek-e meg, mert ez alapvetően meghatározta lehetőségeiket. A sorsformáló tényezők között a zsidóságon belüli vallási irányzatokhoz tartozás is eltérésekhez vezet. Az öltözködés, az életmód és ruhaviselet tekintetében - az azonosságok mellett - mások az ortodoxok, a haszidok és más irányzatok szokásai. Az alábbi képen Beregszász zsidó közösségéből származó, tehát városi gyermekeket látunk, akik egyformán kalapban, nem egyforma, de rendezett ruhában, csoportban, sietős léptekkel igyekeznek valahová, talán a ma is a városközpontban álló zsinagógába. Az arckifejezésük céltudatosságra utal, láthatóan tudják hová mennek és talán azt is, miért. A fejfedők és a felső ruházat egyformaságra utal, de a lábbeli már vagyoni differenciáltságot jelez, hiszen a csoportban két fiú mezítláb közlekedik. A cipő nélküli fekete ruhás fiú felső ruháján is látszik, hogy ez a többiekétől eltérően, nem rá szabott és lóg rajta, feltehetően többen használják a családból. A fénykép vizuálisan is megjeleníti a szellemiségben mutatkozó valamiféle azonosságot, amelyhez azonban életviteli differenciáltság társul. 


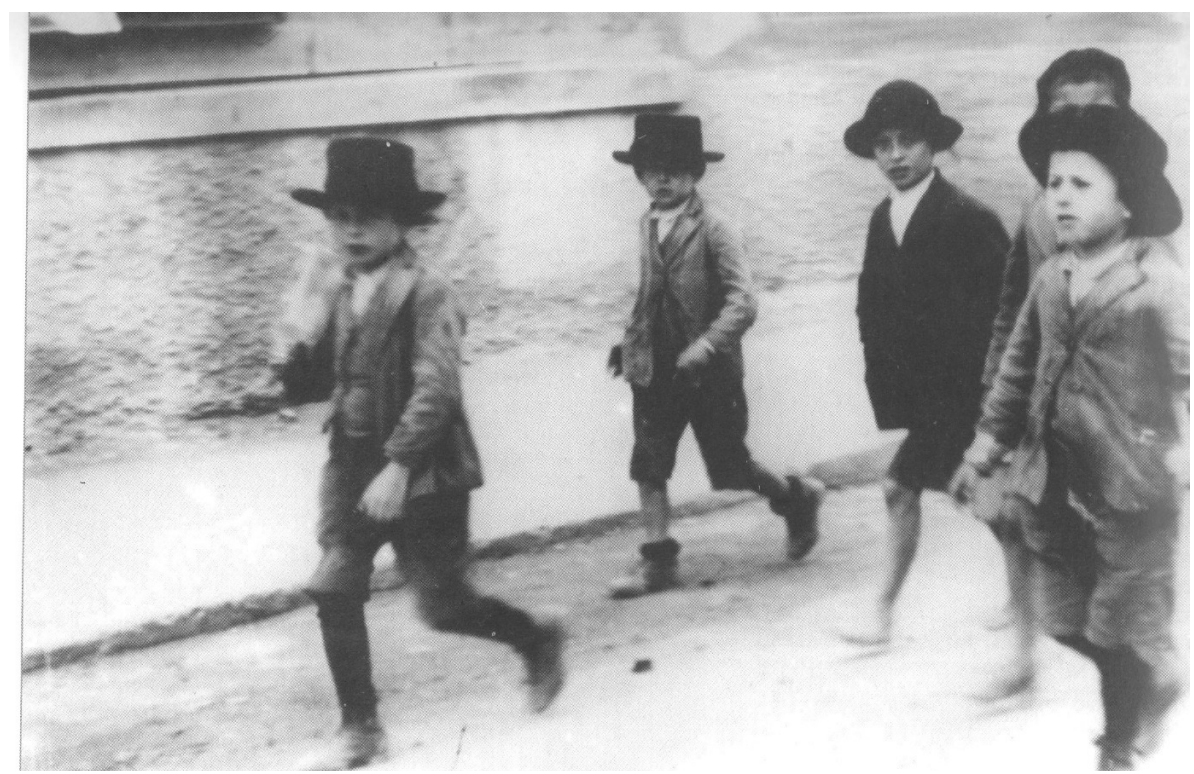

33. kép: Zsidó gyermekek, Beregszász (1930, Földi Rózsi)

\section{Képsorozat a lakáskörülményekröl}

A szociofotó készítői értelemszerủen főleg az rossz körülmények között élőket kapták lencsevégre.

Ebbe a csoportba tartoznak a nyomortelepeken élők és a kilakoltatott családok is. A félig földbe ásott, ezért feltehetőleg nedves kunyhó, meszelt homlokzati vályogfalával és nádazott tetejével arra utal, hogy lakói tartós ott-tartózkodásra rendezkedtek be. A kunyhó a szegényes körülmények ellenére, valamiféle rendezettségre utal, különösen a szakszerủen elhelyezett füstelvezető cső utal erre. Mindez a fényképről hiányzó ügyes kezű férfi jelenlétére utal. A kunyhó előtt álló anya és a kezét fogó kisgyermek testtartása a beletörődésre, az élethelyzet jobb híján történő elfogadására és az ilyen körülmények ellenére valamiféle rend kialakítására utal. Erre leginkább a ruhaviseletből lehet következtetni.

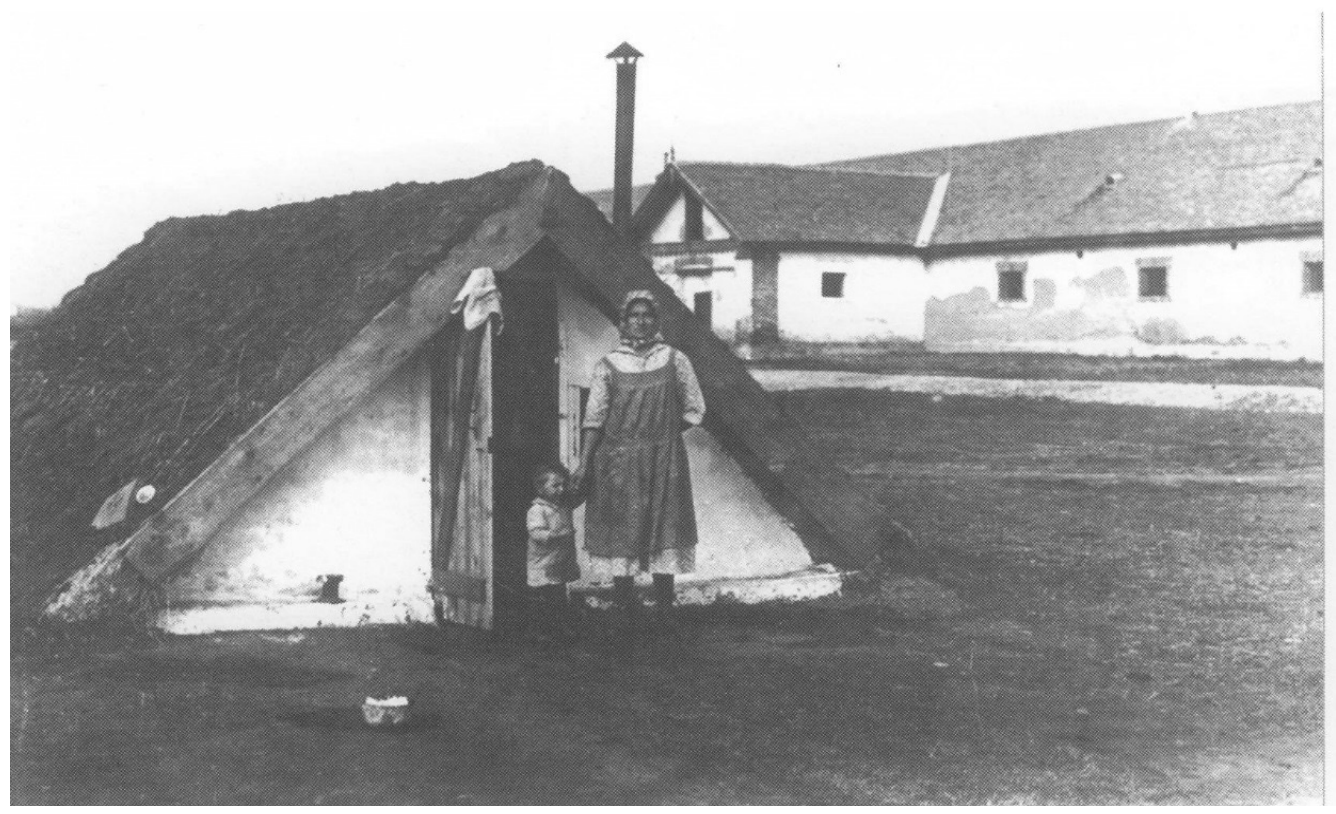

34. kép: Kunyhó egy nyomortelepen (1920, Gyagyovszky Emil) 
Egy másik csoportot képeznek az első világháború utáni menekültek, akik vagonokban találtak maguknak szállást. Közülük nagyon sokan kényszerültek a trianoni döntés után korábbi lakóhelyük elhagyására - köztük sok tanító és más értelmiségi is - akiknek többek között nyugdíjas állásuk miatt kellett lakóhelyüket elhagyni, mert azt az elcsatolt területek hatóságai nem biztosították számukra a nyugdíjat. Az új helyzetben - ha nem voltak rokonaik, jótevőik - arra kényszerültek, hogy a pályaudvarok melletti vágányokra kitolt és átalakított, eredetileg áruszállító vagonokban lakjanak.

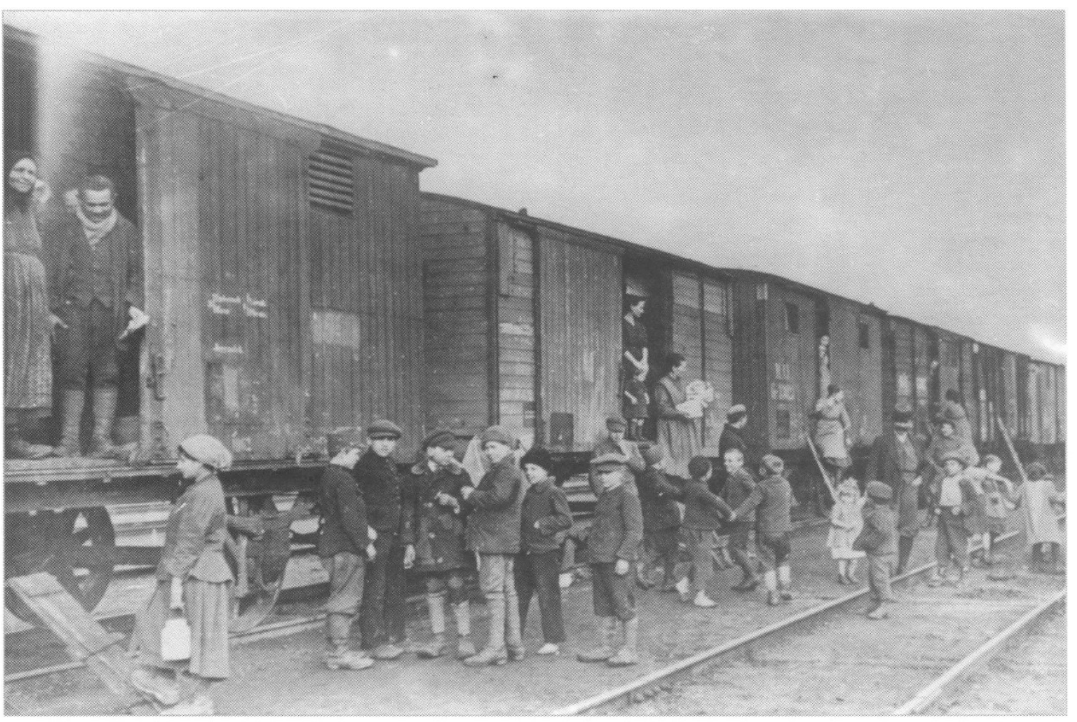

Vagonlakók utcája 1910-20 (Müllner János)

36. kép: Vagonlakók utcája (1910-1920, Müllner János)

Nem sokkal jobbak a körülmények a pro- láthatók. Az anya - talán a kilátástalanságra letár családokban, különösen akkor ha, az apa is utalva - félig takarva, kezét összefonva néz munkanélkülivé vált, vagy ha iszákos, ami a kamerába. meglehetősen gyakran előfordult. A láthatóan szegény családban egymás után születnek a gyermekek. A nagyon kis helyre összeszorult lakótérbe csak egy rongyokkal letakart ágy, csupasz falak és a legszükségesebb edények találhatók. A gyermekek szedett-vedett öltözetben, egymás hegyén-hátán elhelyezkedve 


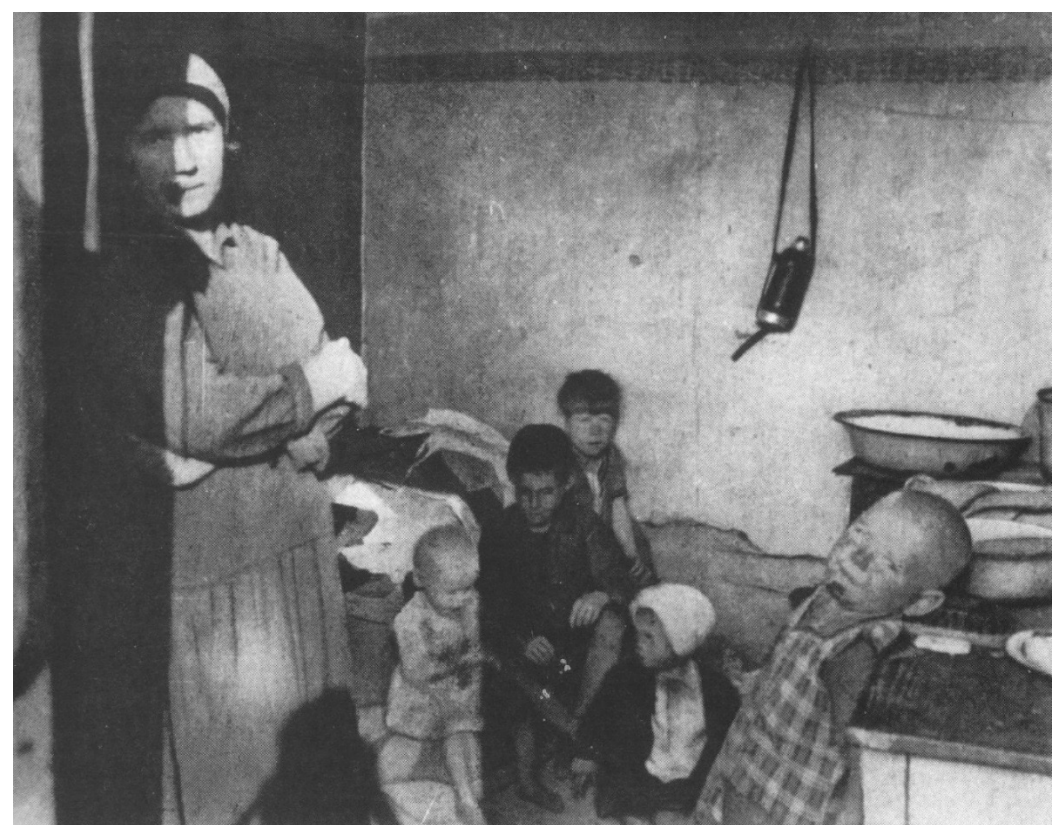

37. kép: Proletárcsalád lakása (1932, Bass Tibor)

\section{Összegzés}

Általánosítva elmondhatjuk, hogy egy fénykép forrásértéke a komplexitásán alapul. Ez egyezikaz életvilág jelenségeinek sokféleségével, míg a fénykép felépítésének módjai pedagógiai és szociális szituációk és viszonyok felépítésének mintáira utalnak. A fényképész és a leképezettek képben elrejtett perspektívái megfelelnek a társadalomtudományok és a történeti kutatás által elvárt multiperspektivitásnak (Pilarczyk és Mietzner, 2010. 7. o.) A fotósok mindegyike szándékot rendelt a képekhez, ez tükröződik abban, hogy mire fókuszált a keresőjében, mikor exponált, hogyan hívta elő a fényképet, retusálta-e azokat. A technikai részletek jelen esetben - bár fontosságuk vitathatatlan - kevéssé kerültek kiemelésre -, inkább a denotációra és a konnotált tartalom kibontásra helyeződött a hangsúly.

Tartalmi vonatkozásban a gyermekek közvetlen környezetének, játékaiknak, segítő tevékenységüknek és életkörülményeinek a bemutatása adalékul szolgálhat a korszak gyermekképének teljesebbé tételéhez. Az étkezéssel kapcsolatos fényképek nagyobb száma a probléma adott korban reálisan létező fontosságára utal. A sajátos élethelyzetek szemléltetése - ami szintén egy sorozatba rendezhető - feltételezi a fényképet néző személy részéről az események továbbgondolását.

\section{Felhasznált irodalom}

Benda József (2016): Gyermeksokk: A megoldások fö irányai... III. rész. Valóság, 59. 3. sz, 20-47.

Buntz, H. \& Erdmann, E.(2004): Fenster zur Vergangenheit. Bilder im Geschichtsuntericht. Band 1. Buchner Verlag, Bamberg.

Buntz, H. \& Erdmann, E. (2009): Fenster zur Vergangenheit. Bilder im Geschichtsuntericht. Band 2. Buchner Verlag, Bamberg.

Gayer Zoltán (1998): Fényképaktusok. Replika, 9. 33-34. sz., 87-102.

Gyurgyák János (2008): Magyarország története képekben I. kötet (A dualizmus kora). Osiris Kiadó, Budapest.

Darvai Tibor (2011): A Tanító című neveléstudományi folyóirat ikonográfiai vizsgálata. 1963, 1970. Iskolakultúra, 21. 6-7. sz., 71-86.

Endrődy-Nagy Orsolya (2015): A reneszánsz gyermekképe. A gyermekkép reneszánsza 1455-1517 között Európában. ELTE Eötvös Kiadó, Budapest

Géczi János (2010): Sajtó, kép, neveléstörténet. Iskolakultúra-Gondolat Kiadó, VeszprémBudapest.

Kéri Katalin (2003): Gyermekkép Magyarországon az 1950-es évek első felében. In: Pukánszky Béla (szerk.): Két évszázad gyermekei. Eötvös József Könyvkiadó, Budapest, 229-245. 
Kéri Katalin (2009): Hervasztó jelen, virágzó jövő. Gyermekábrázolás a Nők Lapja címoldalain az 1950-es években. In: Szabolcs Éva (szerk.): Ifjúkorok, Gyermekvilágok II. Eötvös József Könyvkiadó, Budapest, 111-166.

Kiss Áron (2000): A magyar gyermekjáték gyüjtemény. Holnap Kiadó, Budapest.

L. Menyhért László (2008): Amiről a képi források beszélnek? Iskolakultúra, 18. 5-6. sz., 149-159.

Pilarczyk, U. \& Mietzner U. (2005): Das reflektierte Bild. Die seriell-ikonografische Fotoanalyse in den Erzehungs-und Sozialwissenschaften. Julius Klinkhardt Verlag, Bad Heilbrunn.

Pilarczyk, U. és Mietzner U. (2010): A képtudomány módszerei a neveléstudományi és társadalomtudományi kutatásban. Iskolakultúra, 20. 5-6. sz, melléklet.
Pirka Veronika (2010): Az életreform „megmentés“ motívumának megjelenése a 20. század elején a magyar pedagógiai sajtóban, a Népművelés példája alapján. Iskolakultúra, 20. 7-8. sz., melléklet 3-14.

Sántha Kálmán (2011): A fotóinterjú a pedagógiai architektúra vizsgálatában. Iskolakultúra, 21. 4-5. sz., 55-67.

Schmitt, H., Link, J. W. \& Tosch, F. (1997, Hrsg.): Bilder als Quellen der Erziehungsgeschichte. Julius Klinkhardt Verlag, Bad Heilbrunn.

Stemlerné Balog Ilona (2009): Történelem és fotográfia. Osiris Kiadó-Magyar Nemzeti Múzeum, Budapest.

Szécsényi András (2016): A korszellem hálójában. Gondolat Kiadó, Budapest.

Sziklai László Péter (1993): Humanisztikus Kooperativ Tanulás. Új Pedagógiai Szemle, 43. 12. sz., 73-83.

\section{Lebensbilder und Ikonographie von Kindern am Anfang des 20. Jahrhunderts in Ungarn}

Heutzutage verwendet man in der Erziehungsgeschichte immer öfter ikonographische Elemente, da die Bilder sehr plausibel den Text und andere Narrativen ergänzen können. Zur Darstellung stehen diesmal Fotographien von unterschiedlichen Künstlern zur Verfügung. Die insgesamt von Anfang des 20. Jahrhunderts stammenden 146 Photographien wurden von unterschiedlichen Sammlungen ausgesucht und thematisiert. Es wurden folgende Themen dargestellt: Soziofotos, spielende Kinder und ihre Spielzeuge, Kindern in wohlhabende Familien, Kind mit Amme, Kinder beim Essenausteilung, Kinderarbeit, Tragedien in Kinderleben, Kinder in der Roma Familie, jüdische Kinder, Flüchtlinge und ihre Wohnverhältnisse. Die Photographien sind einzeln, zwei parallel nebeneinander oder in die Reihe geordnet dargestellt. Die multiperspektivische Darstellung mit dem dazugehörenden Text sichert einen komplexen Einblick in das Kinderleben von dem damaligen Ungarn.

Keywords: Fotos von Berufsfotographen, thematisiertes Kinderbild, komplexe Darstellung, selbstständiges Foto, parallele Darstellung, Reihenordnung bilden

Mikonya György (2017): Ikonográfia és életképek a 20. század eleji Magyarországról. Gyermeknevelés, 5. 1. sz., 64-84. 